\title{
Pierre-Ignace-Liévin van Alstein Gents slavenkapitein in Nantese dienst
}

\author{
$(1733-1793)$ \\ door \\ J. EVERAERT \\ Aspirant N.F.W.O.
}

De levendige Loirehaven en de met haar 18de-eeuwse topbloei onafscheidelijk verbonden driehoekshandel, leverden het decor waarin de hiernavolgende biografie zich afspeelde. De eigenlijke slavenhandel vormde slechts een schakel in het complex dat de tijdgenoten zeer precies als „commerce triangulaire" of "commerce circuiteux" bestempelden. Deze kringloop-economie was immers gegrondvest op drie verschillende transacties: vanuit het knooppunt Nantes werd de ruilwaar naar het zwarte continent aangevoerd; het „bois d'ébène" vond in negercargo's zijn weg naar de Caraïbische plantages, vanwaar de tropische produkten tenslotte naar het moederland afvloeiden.

Ons studiemateriaal troffen we aan in de registers en bundels van het Fonds d'Hoop (afkorting F.H.), berustend in het Rijksarchief te Gent. In de analytische inventaris van dit fonds ( $n^{\circ} 171$ ) staan desbetreffende manuscripten geklasseerd onder de rubriek Varia: Documents concernant la traite des nègres (F.H. n ${ }^{\text {or }}$ 965-983). Deze handelsdocumenten vulden we aan met gegevens geput uit de Correspondances (F.H. $\mathrm{n}^{\circ 8}$ 351-367) en de Actes de Famille (F.H. n $^{\circ 8}$ 959-964). Een latere schenking bevat van Alsteins private comptabiliteit (F.H. suppl. n ${ }^{\circ} 56$ - fragmentair).

Tenslotte illustreren we hier in voetnota aan de hand van enkele contemporaire gegevens de koopkracht van het pond tournois ( $f t$ ) en het $1 / 3 \mathrm{~min}$ derwaardige koloniale pond $(f c)$.

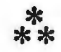

\section{Koopkracht van het pond:}

Pond Tournois : 1 mois de louer d'un appartement (Nantes): 30 ; au dentiste pour arracher une dent : 6 ; un paire de souliers : 6 ; un habit (veste, culotte) complet de soye, façon et fourniture : 126 ; un baril de farine : $34 ; 2 \mathrm{lb}$ de tabac: 7 ; 3 comédies au theatre : 6 .

Koloniaal pond : 1 mois de pension : 180; I mois de blanchissage: 18; fourniture et façon d'une veste : $156 ; 1 \mathrm{lb}$ de viande : 10;1 baril de farine : 100 ; abonnement ( 5 représentations) de comédie : 30 . 


\section{STAMBOOM DER FAMILIES VAN ALSTEIN - GOUGH}

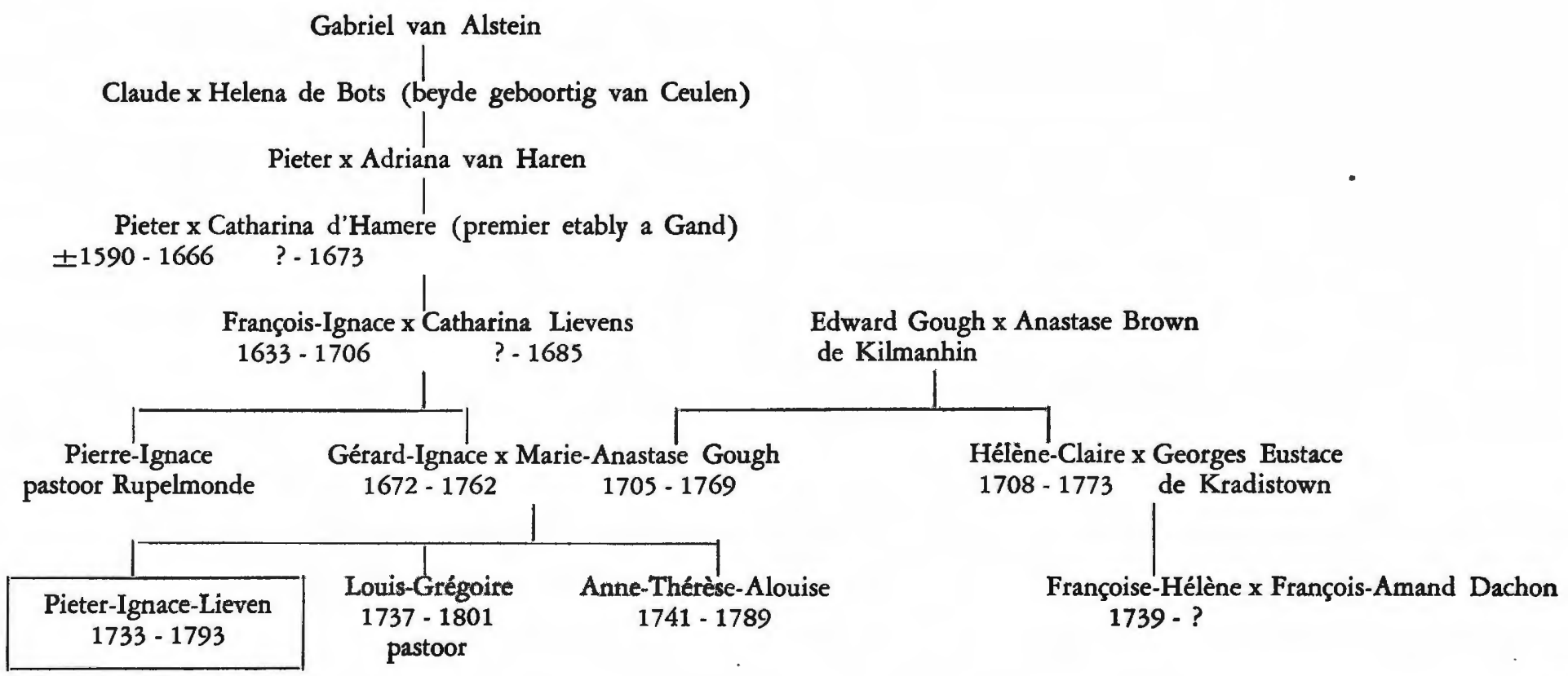


A.

\section{GENEALOGISCH-SOCIALE SITUERING.}

\section{Historiek van het geslacht van Alstein.}

De bakermat der familie van Alstein ligt hoogstwaarschijnlijk in het Rijnland, waarop overigens ook de Duitsklinkende naam zou wijzen ${ }^{1}$. Een „Arbor Consanguinitatis" klimt op tot de eeuw van Karel V met de voor de rest onbekende "Jor Claude van Alstein f: Gabriel, trauwt met joffe Helena de Bots, beijde geboortig van Ceulen." 2 Hun kroost zwermde uit en bracht het soms tot sociaal welstellende posities: „Steven, capiteijn tot Straesborgh, sterft sonder hoirs; Marie, abdisse tot Liere in de abdije van S. Bernardus; Antonette, penitente tot Leuven; Gabriel, secretaris sonder hoirs tot Ceulen". Alleen Pieter zal het geslacht voortzetten en "trauwt met joffe Adriana van Haren" te Keulen.

Zijn gelijknamige zoon ${ }^{3}$ „Pierre, premier etably a Gand... ayant atteind environs 29 ans, il se mariat le 24 janvier 1619 en l'eglise paroissiale de St Michel de Gand, avec Catherine D'hamere, d'honnorable et noble famille de ce quartier..." 4 .

Achtereenvolgens bekleedde hij de post van „baillage ou greff” der baronie Nevele en in de kasselrij van de Oudburg te Gent ${ }^{5}$. Overleden te Gent op 1 mei 1666, ,agé de 76 ans (dus rond 1590 geboren) ayant toujours vecu noblement et consideré dans le pais..." werd hij geborgen in zijn nieuwverworven grafkelder in de $\mathrm{S}^{t}$ Michielskerk, waar zijn vrouw op 24 juni 1673 werd bijgezet ${ }^{6}$.

(1) F.H. 361 - Correspondentie P.I.L. van Alstein aan zijn broer Louis-Grégoire; Gent, 2 juli 1772 . Bij zijn genealogische navorsingen kwam de slavenkapitein eveneens terecht "A Cologne sur les Registres Van Alstede".

(2) F.H. 962 - Arbor consanguinitatis familiae Alstein (Struyken famillien). Stamboom vermoedelijk daterend uit de vroege $19 \mathrm{de}$ eeuw en opgesteld naar aanleiding van de toewijzing der erfenis van priester Louis-Grégoire. Voor de opbouw van deze familieschets benutten we verder: Extrait des divers manuscrits des predecesseurs de la famille Waldstein... finalement van Alstein (F.H. 961). Genealogisch overzicht, tussen 1781-86 door P.I.L. persoonlijk opgesteld bij een - bedrieglijke - poging om het familieblazoen te "redoreren".

(3) De dochter „Alphonse, trauwt met $\mathrm{Jo}^{\mathrm{r}}$ Eduaert de Grits, sonder hoirs in Enghelant".

(4) F.H. 961 - Extrait...; P.I.L. verwart hier onbewust datum en kerk, zoals duidelijk blijkt uit de authentieke huwelijksbelofte - Extract de banis a l'eglise St.Michel le 24 janv. 1619 - en trouwakte - Extract de mariage de l'eglise St. Nicolas du $20 \mathrm{fr}^{\mathrm{r}} 1619$-, beide vermeld in zijn brief dd. 1772 (F.H. 361).

(5) De groot-baljuw, een della Faille, was tevens peter van de zoon Joris van Alstein ( ${ }^{\circ} 1631$, gehuwd met Marguerite Brias, descendante des Milan de Visconti). $\mathrm{Na}$ rechtstudies aan de universiteit van Dôle in Boergondië nam hij vaders functie over (F.H. 964 - copij 1772; deze vrijgeleide in 1652 te Besançon afgeleverd preciseert : „... George d'Alstein gentilhomme hollandois... ayant séjourné quelque tems, commencor en d'aultres villes de la Province pour apprendre les exercices de sa condition...")

(6) P.I.L. bezocht in 1781 deze „caveau... situé au milieu du cœur de l'église paroissiale de St. Michel de Gand ou il existe encore une pierre de marbre avec in- 
Van de negen kinderen gingen er twee op in de geestelijke stand - kanunniken respectievelijk te Aire en St Omer - ; de rest huwde. P.I.L. van Alsteins grootvader, François-Ignace - tweelingbroer van Jean-Baptiste geboren op 30 aug. 1633, werd door zijn broeder-kanunnik Pieter op 12 dec. 1665 in de St.-Baafskathedraal in de echt verbonden met Catharina Lievens. "Lissencié et avocat au conseil de flandres", stierf hij op 6 okt. 1706. $\mathrm{Na}$ twintig jaar huwelijksleven - Catharina ontviel hem reeds op 13 jan. 1685 - telde het gezin negen kinderen „qui ont pris le party de la Religion, pretres et religieuses", uitgenomen Gérard-Ignace, op 14 jan. 1672 in St.-Baafs gedoopt.

Handelaar, residerend te Gent, ging hij er een eerste huwelijk aan met Barbe Marie Dem, dat echter kinderloos bleef. Weduwnaar geworden, maakte hij kennis met de 22-jarige, te Duinkerken geboren (28 aug. 1705) Marie-Anastase Gough, dochter van een adellijke Ierse emigrant, wiens echtgenote na zijn dood te Parijs een bank beheerde ${ }^{7}$. De inzegening werd voltrokken op 25 aug. 1728 in de Parijse parochiekerk St.-Merry ${ }^{8}$. Het huwelijkscontract werd opgemaakt „sous les loix et usages de la coutume et echevinage de la ville de Gand". Als bruidschat graf de gefortuneerde Anastase Brown aan haar dochter - evenals trouwens aan elk harer overige huwende kinderen - het klein fortuin mee van „20.000 livres tournois en especes de louis d'or et d'argent" 9 . In geval de bruidegom eerst overleed wat niet denkbeeldig was gezien zijn 56 jaren — zouden de bruid toekomen „l'ameublement entier du menage, la vaiselle d'argent, joïaux et tous autres meubles meublans et corporels". Deze bepaling verklapt de sociale welstand van koopman van Alstein.

Het nieuwe gezin, ,ayants faits election de leur domicile en la ville de Gand $y$ ont demeurés et $y$ ont eu huit enfants" ${ }^{10}$. Vader van Alstein bereikte de hoge leeftijd van meer dan 90 jaar; overleden te Gent op 21 maart 1762 liet hij zich bijzetten in dezelfde familiekelder, waarin ook zijn ouders reeds rustten. $\mathrm{Na}$ haar mans dood, verhuisde M.A. Gough naar Komen op de Leie, waar ze ontsliep op 22 feb. 1769, 64 jaar oud.

scription Piter Van Alstein et Catharina D'hamere". (F.H. 961 - Extrait...); Grafen Gedenkschriften der Provincie Oost-Vlaanderen, 1ste reeks: Parochiekerken : Gent, Deel I (1865) : Sinte Michielskerk; p. 153 : Plan der grafkelders in het koor, p. 152: Familiën die daer hare grafkelders hadden: $n^{\circ} 23$. van Alstein, (tussen Van den Berghe en Vander Haeghen, op ongeveer $13 \mathrm{~m}$. van de N.O. hoofdpijler der kruisbeuk).

(7) F.H. 959 - Uittreksel huwelijksakte.

(8) De kerk is gelegen aan het kruispunt der Rue de la Verrerie en Rue St. Martin. Gérard-Ignace logeerde overigens occasioneel in het Hôtel Chalon, gelegen in deze laatste straat. De parochie St. Merri ligt, in volle stadscentrum, benoorden het Ile de la Cité.

(9) F.H. 959 - Extrait du Contract de mariage de mon pere Gérard van Alstein, Ecuier, et de ma mere $d^{110}$ Marie-Anastase Gough fait a Paris le 21 aoust 1728 (origineel op gezegeld perkament). De som vertegenwoordigde fl. 11.180 courant.

(10) Felix-Henri d'Hoop, La famille van Alstein, ses escendants, descendants et leurs alliés, Gent, 1891, p. 6 - Anastasie (1730-51), Edouard (1731-59), PierreIgnace-Liévin (1733-93), Louis-Grégoire (1737-1801) en Anne-Therese-Aloîse (17411789); 3 kinderen stierven in de wieg: Pierre-Ignace (1732); Jean-Baptiste (1735) en Marie-Thérèse (1745). 
Slechts drie harer kinderen overleefden haar: kapitein Pierre-Ignace-Liévin, pastoor Louis-Grégoire en de jong gebleven Anne-Thérèse Alouise.

De jongste zoon, Louis-Grégoire, zag het daglicht te Gent op 31 jan. $1737^{11}$. Priester gewijd in het bisdom Ieper, vervolgens in 1765 tot pastoor aangesteld te Bixchotte (Bikschote ten $\mathbf{N}$. van Ieper op de Ieperlee) werd hij tenslotte op 15 juni 1781 plechtig ingehaald als zieleherder te Reninghelst (ten Z.W. van Ieper). Tevens was hij titelvoerend ,chapelain de castedrale de Peteghem" 12. Uit verzet tegen de wet op de beëdiging der priesters liet de pastoor op 3 frimaire an 6 (eind nov. 1797) zijn parochie in de steek, officieel ,a cause de ses infirmités et affoiblissm ${ }^{t}$ de sa vue". Achter deze drogreden ging echter de echte oorzaak schuil: „n'a pas encore prete le serment". Voor de republikeinse administratie was hij voortaan slechts een ,rentier, domicilié dans la commune de Gand, section de la reunion, $\mathrm{n}^{\circ} 170^{\prime \prime}{ }^{13}$. Hij overleed er op 17 nov. 1801. Met hem verdween de laatste telg uit deze tak der van Alsteins. Immers zijn zuster Anne-Thérèse, geboren 20 sept. 1741, bleef - evenals P.I.L. - ongehuwd; ze stierf in de Arteveldestad op 3 dec. 1789.

\section{De Nantese relaties der families Gough-Brown ${ }^{14}$.}

De grootouders van P.I.L. langs moederszijde waren adellijke emigranten die de katholieke koning James II in ballingschap vergezelden naar het Frankrijk van Louis-Soleil. Zijn grootvader, Edward Gough of Kilmanhin (verbasterd tot Kilmanheim), in het graafschap Waterford, ,qui avoit des biens considérables en fond de terre dans les comtés de Corke et de Waterford dans le Royaume d'Irlande", vestigde zich na de uiteindelijke nederlaag van de Ierse opstand en de proscriptie uitgevaardigd door de protestant Willem III (1689) te Duinkerken ${ }^{15}$. Hij zette er een winst-

(11) Peter was Pierre-Grégoire van Alstein, advocatus in consilio flandriae, zoon van de hogergenoemde Joris en kozijn van de vader (F.H. 959 - Uittreksel geboorteregister).

(12) op. cit., annex G, p. 273 ; F.H. suppl. 56, $f^{\circ} 15 \mathrm{v}^{\circ}$. Vermoedelijk is dit Peteghem-bij-Oudenaarde. Ook Ferdinand, broer van zijn betovergrootvader en ka. nunnik te Aire, was „en 1697 chapelain du Château de Peteghem-lez-Audenarde", eigendom der familie Brias (op. cit., p. 189).

(13) F.H. 366 - Tabelau des Prêtres qui depuis la publication de la loi du 19 fructidor, an 5 ont quitté leur domicile (5 sept. 1797) - F.H. 64, $\mathrm{n}^{\circ} 219-$ Copij verkoopakte 4 frimaire, an 6.

(14) F.H. 959 - De gegevens putten we uit twee mémoires, gedrukt naar aanleiding van erfenisprocessen - Memoire ... pour Dame Marguerite Brown, veuve du Sieur Joseph Comerfort, Seigneur de la Terre d'Anglure, Irlandois naturalisé dans le Royaume... (1747); Memoire pour Edouard \& François Gough, Ecuyers \& Demoiselle Anne-Marguerite Gough, leur sœeur... (1742). Verder uit P.I.L. van Alsteins genealogische nota's : "La famille de ma grande mere maternelle Madame Anastase Brown Gough" (1787?); de "Titres de Noblesse d'extraction de la $D^{*}$ Mere de S. Van Alstein" (1781) en de "Papiers concernant la famille Gough".

(15) Edward zetelde in James' II anti-revolutionair parlement van Dublin in april 1689. Later bevestigde de troonloze kroonopvolger James III, in zijn ballingsoord St.-Germain-en-Laye, de adelbrieven (26 april 1709). De zoon François diende in een Iers regiment in Franse dienst. 
gevende maritieme handelszaak op touw en huwde er zijn land- en lotgenote Anastase Brown.

In mei 1718 liet Gough zich, samen met zijn familie, naturaliseren met behoud van hun blazoen en adellijke prerogatieven ${ }^{16}$. Ondertussen had hij zich als gefortuneerd koopman uit de zaken teruggetrokken en zich reeds te Rijsel gevestigd. $\mathrm{Na}$ zijn dood in 1721 , verhuisde de weduwe met haar kinderen naar Parijs waar ze met haar kapitaal een bank opende in de "rue neuve, paroisse Saint-Mery”, waar ,... elle louoit un appartement a 1800 1; avoit un bon équipage, bien entretenu, une maison étoffée". Een dochter, Marie-Anastasie huwde er Gérard-Ignace van Alstein.

De overige kinderen - toekomstige ooms en tantes van P.I.L. - verspreidden zich meestal. Edward vestigde zich opnieuw te Duinkerken; François vertrok in 1731 naar Rouen; Jean Baptiste ,,acolite du diocese d'Ypres" in feb. 1727, was er het jaar daarop diaken; Jacques huwde een dochter der Nantese groot-reders Walsh en week later uit naar Cádiz, waar zijn zoons Jacques en Edward reeds in 1776 het handelshuis beheerden. Hélène-Claire trouwde in 1735 te Parijs Georges Eustace de Kradistown, zoon der Ierse emigranten Guillaume en Marie Aylmer; ze vestigden zich in Nantese St.-Niklaas-parochie, waar hun in 1739 een dochtertje FrançoiseHélène werd geboren. Anastase-Lucie verbond zich met Louis-Luc de Commerford, Marquis d'Anglure, eveneens telg uit een Iers geslacht.

Ook de familie der grootmoeder M.A. Brown waren politico-confessionele uitwijkelingen: „les Brown, trés atachés a leur Prince le Roy Jacques, lors les révolutions d'Irlande pour éviter beaucoup de desagrement, quitterent leur pais natal pour se fixer en diver pais ou ils pourroient exercer librement leure religion Catholique Romaine". De Ierse bannelingen burgerden zich in op Spaanse en Franse bodem ${ }^{17}$. Drie broers vestigden zich respectievelijk te Bilbao, Brugge en Saint-Malo. Een dochter uit de tweede echt van de Bretoense weduwe van deze laatste - overleden oom van P.I.L. van Alstein - nl. Marie-Anne de Canisburg, huwde met Patrice Walsh, broer van de Nantese reder Antoine-Vincent, stichter der Société d'Angola, een slavenhandelscompagnie ${ }^{18}$. Een zuster, Marguerite, gehuwd met graaf Joseph de Commerford uit Dublin, was de schoonmoeder van Anastase-Lucie Gough. Tenslotte, via de Browns en vooral dank zij de aangetrouwde Walsh, waren de van Alsteins verder enigszins verwant met de magnaten uit de Nantese rederswereld als O'Shiell, Grou, Bouteiller, en Portier.

(16) Op 15 juni 1722 werd hij inderdaad - posthuum! - opgeroepen om te Rijsel in de ,assemblée des ecclesiastiques et nobles de la province" te zetelen.

(17) Gaston-Martin - Nantes au XVIII' siècle: L'ère des Négriers (1714-74), Paris 1931, pp. 240 sq.

(18) F.H. 959 - Freres \& Sœurs de ma grande mere dont nous avons eu connoissance. 
B.

\section{DE LOOPBAAN VAN DE SLAVENKAPITEIN P.I.L. VAN ALSTEIN}

\section{Een bewogen jeugd.}

Pierre-Ignace-Liévin van Alstein werd te Gent in de voormiddag van 11 nov. 1733 geboren als tweede „filium D. Gerardi Van Alstein, armigeri et D. Mariae Anastasiae Van Gough conjugum". Bij het doopsel in de St.-Jacobskerk kreeg hij als voornamen deze van zijn peter, Pierre-Ignace, vaders broer en pastoor te Rupelmonde; Lieven werd er aan toegevoegd ter onderscheiding van een in de wieg gestorven broertje Pierre-Ignace. Philippina Brown verving de afwezige Parijse meter, Anne-Marguerite Gough ${ }^{19}$.

$\mathrm{Zijn}$ verdere jeugd te Gent is omzeggens onbekend, tenzij dat hij college liep in het Ste-Barbara-instituut der Jezuieten ${ }^{20}$. Op 12-jarige leeftijd maakte hij reeds kennis met het oorlogsgeweld, gebeurtenis die zijn verdere leven gans zou wijzigen. Tijdens de Oostenrijkse Successieoorlog, toen Franse legerbenden in 1744-45 Vlaanderen onder de voet liepen, bleef het bezette Gent evenmin gespaard van oorlogsschattingen en verplichte recrutering. Vader van Alstein bracht zijn opgroeiende zonen in veiligheid: Edouard bij zijn oom Edward Gough in Duinkerken ${ }^{21}$; Pierre-IgnaceLiévin vertrok in 1748 naar Nantes waar zijn tante Hélène-Claire Gough resideerde.

Oom Georges Eustace, kleine reder, beleefde echter donkere tijden. De Engelse blokkade der Franse havens en de kaperij der Britse oorlogsbodems in de Caraïbische zee verlamden tussen $1745-48$ praktisch alle trafiek, de winstgevende negerhandel inbegrepen ${ }^{22}$. P.I.L. wou echter geen misbruik maken van de gastvrijheid, die voor zijn intussen gefailleerde oom wel een last moest zijn. Met de vrede van Aken (okt. 1748) hernam de Nantese havenbedrijvigheid. Langsheen de Loire-kaaien en in de vóórhaven Paimbœuf was er vraag genoeg naar zeelui. De jeugdige Gentenaar zou hier zijn levenskans wagen.

\section{De maritieme opleiding.}

Zijn maritieme loopbaan begon van Alstein als „novice" (lichtmatroos) op de Montmartel. Deze vrachtvaarder, toebehorend aan de Compagnie d'Angole, verliet in okt. 1749 de Loiremonding met directe bestemming Saint-Domingue (Haït). De opgepropte stocks koloniale produkten en de

(19) F.H. 982, $\mathrm{n}^{\circ} 4-$ Extractum ex Registro Baptismali ecclesiae parochialis Sti Jacobi Gandae... (gezegeld perkament - 3 jan. 1787).

(20) Een reminiscentie aan zijn Gentse schooltijd duikt op wanneer hij het boordjournaal van de Mars (F.H. 967-1755) opent met het devies der Jezuietenorde : „Ad majorem Dei gloriam".

(21) Edouard ( $\left.{ }^{\circ} 1731\right)$ benoemd tot Spaans vice-consul te Duinkerken, overleed er in 1759. Ook zijn zuster Anastasie stierf buiten haar vaderland, nl. te Béthune (1730-51).

(22) Gaston-Martin, op. cit., pp. 225-235. 
dringende behoefte der Caraïbische planters aan moederlandse manufacturen en proviandering, loonden voorlopig meer een uitreding naar de parel der Franse koloniale kroon, eerder dan een steeds riskante slavencampagne. De Montmartel bevoorraadde er Cap-Français - de commerciële metropool op de N.-kust van het eiland - en liep half nov. 1750 terug Paimbouf binnen, geladen met suiker, koffie, indigo en katoen ${ }^{23}$. Slechts 16 jaar oud, aangeworven zonder soldij, was voor P.I.L. het avontuur begonnen dat hem van het ruwe leven midden ongeletterde Bretoense zeebonken zou voeren naar het benijdenswaardig bestaan van een gefortuneerd zeekapitein op rust.

Langer dan een kleine vijf maand duurde het verblijf aan wal niet, genoeg echter om het certificaat van ,pilotin" te verwerven dank zij de gratis leergangen in wiskunde en hydrografie die de Jezuieten sedert 1671 te Nantes organiseerden. Gewapend met voldoende kennis om de scheepspositie te kunnen bepalen en het boordjournaal bij te houden, nam hij opnieuw dienst op dezelfde éénheid, nu echter als aspirant-stuurman.

Begin april 1751 zeilde het schip, deze maal als negercargo ,naar Malimbe in de huidige Portugese enclave Cabinda. Zes maand volstonden om er 658 zwarten in het ruim te tassen. $\mathrm{Na}$ de geslaagde veiling te Cap-Français, keerde de 350-tonner met campeche-hout, suiker en koffie terug en meerde op 24 juni 1752 te Paimbœuf 24. Hiermee had van Alstein de doop der driehoeksvaart ondergaan.

De compagnie verving de Montmartel door de Economie. Pas aangemonsterd, ving P.I.L. reeds in sept. 1752 als ,enseigne” (aspirant-officier) zijn tweede driehoekscampagne aan. De negercargo sloeg zijn mensenlading in te Loango (ex Frans-Congo). Vermits de eerste „enseigne” geen voldoening gaf, kreeg van Alstein het scheepsjournaal toegewezen voor „... la traversee de la cote d'Angolle pour l'ile Saint-Domingue en 1753". Een buikloopepidemie woekerde onder de zwarten en spaarde evenmin de bemanning. De „négrier" zocht hulp in de rede van St.-Pierre de la Martinique: „j'ai ete 3 jours a la Martinique a courir les champs pour me desenfler les jambes". Het laatste traject duurde „... quinze jours avant de mouiller aux Cayes pendant lesquels jai ete tres malade...; nous avons fait une assez bonne vente...". Daar de ganse staf eveneens ziek viel signaleerde P.I.L. niet zonder fierheid "qu'aux Cayes il a ete commandant portant flamme...". Op 19 juli 1754 vaarde de Economie terug de Loire op ${ }^{25}$. Het contract der Société d'Angolle liep na vijf jaar ten einde. De 21-jarige Gentenaar moest nu een andere reder zoeken dan Antoine-Vincent Walsh op wiens schepen van Alstein een bijna ononderbroken lustrum gediend had ${ }^{26}$.

(23) Ibidem, pp. 250, 253 - De eenheid, gedoopt naar één der aandeelhouders Paris de Montmartel, kwam pas van de werf op 16 sept. 1749. - D. Rinchon, Le trafic négrier, Brussel-Parijs 1938, p. 60.

(24) ibidem, p. 61. - Gaston-Martin, op. cit., p. 254.

(25) F.H. 966 - Boordjournaal Economie (fragmentair). De haven „Cayes de Saint-Louis fond de l'isle a Vache" ligt op een Z.W. schiereiland.

(26) V.A. Walsh trok zich uit de rederij terug en werd voor zijn verdiensten geadeld; P.I.L. betitelde hem overigens als Milord. 
Voortdurende incidenten en de vrees voor een dreigend zeeconflict met Engeland beperkten de uitredingen. De definitieve loopbaan was echter gekozen. Toen verlokkende hoge winsten J. Darecche toch tot de uitreding van zijn Mars overhaalden, scheepte van Alstein zich zonder veel talmen andermaal, in 1755, als tweede luitenant in. Het slavenschip, dat zijn mensenvracht te Malimbe ${ }^{27}$ verworven had, werd echter onder de Haïtaanse kust door Britse oorlogsbodems gepraaid: „le 8 avril (1756) nous avons ete pris par un vaisseau et une fregatte angloise a 8 lieues du Cap qui nous conduit a la Jamaique". De zevenjarige oorlog was officieus gestart.

\section{De oorlogscampagne.}

$\mathrm{Na}$ verkoop der gekaapte negerlading in de rede van Port-Royal (Kingston) werden de Franse krijgsgevangenen geïnterneerd in een ,... navire de la Rochelle... et nous etions a bord plus que 400 francois tant officiers que matelots". Na een klacht bij de Engelse admiraal werden de officieren overgeplaatst op de Nantese Succes ,ou nous avons vecu tres long temp tranquillement, mais ennuyé de n'aller pas a terre". Op raad van zijn kapitein J. Deurbroucq liet hij de kans varen om met een schip uit Curaçao te ontsnappen. Begin aug. moest hij aan wal, „... pour y rester quelque temp, ayant la bouche un peu endomagé d'ecorbute; $j$ 'ai loue une petite chambre... ou je vivais assez misérablement".

Pas op 25 aug. 1765 afficheerde men de officiële oorlogsverklaring aan Frankrijk. De kolonne geïnterneerden werd naar Spanishtown geëvacueerd; de Britse autoriteiten huurden voor de officieren een gratis woning: „cette maison commune etoit une resource pour ceux qui etoient a court d'argent" ${ }^{28}$. Na lange palabers over de vergoedingen - „pendant tous ces differens, ceux qui n'avoient pas d'argent ne mangoient guerre et crioient la faim" - ontvingen de voorname krijgsgevangenen uit de locale schatkist een kleine gage. De gewone matrozen ontvingen hetzelfde rantsoen als vroeger "qui surement est tres mediocre". Een verzoekschrift tot vrijlating bleef zonder effect ${ }^{29}$. De Britse gouverneur sloeg blijkbaar geen

(27) F.H. 967 - Journal du Mars. - Te malimbe meerde toevallig ,la princesse d'Angolle, capitaine Beauman, avec lequel j'ai fait deux voyages de la coste et un a St. Domingue". In dit register noteerde van Alstein verder uitvoerig alle gebeurtenissen betreffende de slavencampagne en zijn verder wedervaren op Jamaïca en bij de Franse krijgsmarine.

(28) De Fransen genoten er trouwens een verregaande vrijheid : „outre cela nous avions permission de louer des maison avec les même prerogatifs que les gens du pays ; ... Beaucoup de françois se sont mis en pension chez des mulatresses ou negresses" (F.H. 967).

(29) F.H. 967 - Journal du Mars : 26 jan. 1757 - lettre courte au gouverneur : Tot mijn Heer, Mijn Heere den gouverneur van deze Ylandt Jamaique. Gelijck ick eenen holander geboren ben ick hope dat gij mijne sacke sult aenhoren, ick en hebbe maere eene rijse gedaen in den franckendienst voor jongman met Mijnheer deurbrouq. Daer en was genen orlogh als ick uijt franckerijck kommen ben en als sij mij genomen hebben, tis waerom ick vrage $U$ mijne vreyschap en ick sal in mijn landt wederom keeren in eenighe Englecke schepen, ick verwachte van $U$ eene goede aentworde en ick sal altijt wesen, Mijn heer den Gouverneur, U ootmoedigen en onderdanigen Dienaar P. Vanalstein. 
aandacht op de in gebroken Vlaams opgestelde petitie. Einde maart herleefde de hoop: een Frans eskader, gestationeerd te Cap-Français, kaapte een Brits fregat. De koehandel begon: in ruil wisselde men de zeelui uit. De Flagatown zette de gerepatrieerden aan land te Cayes op de Haïtaanse zuidkust, daartoe door de opvarenden gedwongen i.p.v. in het nabije St.-Louis.

Hier had van Alstein vrienden: j'ai resté 40 jours sur l'habitation a

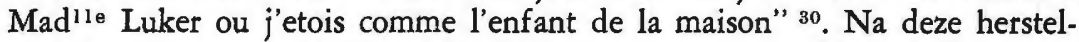
periode engageerde P.I.L. zich als hulpstuurman op de Opiniâtre, een Franse oorlogsbodem die de handeldrijvende lijnschepen escorteerde. Via Port-au-Prince en St.-Marc bereikte het konvooi Cap-Français. De sprong naar huis dwars door de Britse blokkade naderde.

Bij een eerste poging om naar Frankrijk over te steken, werd het eskader in een bloedige zeeslag gewikkeld ${ }^{31}$. $\mathrm{Na}$ kalefatering der opgelopen schade slaagde het volgend opzet; de volledige vloot - ,4 vaissaux dont un armé en flutte, deux fregades et un gabare du Roy, et 40 navire marchands, navires, senot, brigantin, goelettes et bateaux" - ontsnapte. Bij de vervanging van de gesneuvelden op de Opiniâtre "on m'a mis chef de la onzieme piece de canon de 24 et a la batterie basse". Binnengelopen te Brest op 13 jan. 1758, ,j'ai ete 40 jours... dans le fort de la maledie; mon capitaine me fit congedier".

Eervol ontslagen met een vergunning „de se retirer chez lui jusqu'a nouvel ordre", bood hij zich vergeefs op het marinekantoor te Nantes aan. Alleen een geschreven „decoratie" van zijn oud-commandant Moëlien bleef zijn beloning ${ }^{32}$.

Tijdens de Zevenjarige Oorlog (1756-63) lag de driehoeksvaart volledig lam. Alleen een paar durvers forceerden de blocus om Saint-Domingue te bevoorraden aan woekerprijzen. Toen de vroegere beheerder der Angola$\mathrm{C}^{\mathrm{ie}}$, Milord Walsh, besloot persoonlijk zijn plantages op Haïti in handen te nemen, liet hij zijn vertrouwensman François Jogues de Brocanteur uitrusten en voorzien van kapersbrieven. In het najaar van 1758 nam hij als tweede-kapitein van Alstein in dienst, die in de handels- en oorlogsmarine reeds zijn sporen verdiend had voor de nakende gevaarlijke overtocht om op eigen houtje de kolonie te bereiken. In de baai van Morbihan, „Milord Walsh est venu a bord avec son fils, l'aumonier $M$. Plouvier, son nègre cuisinier et un valet de chambre, avec toutes ses malles pour partir avec

(30) De suikerplantage behoorde toe aan de Chevalier de Luker, negotiant-reder te Nantes; Van Alsteins overgrootvader Jacques Gough huwde Jeanne de Luker. Nicolas Luker was vicaris te Nantes en verenigde te Ancenis de dochter van Georges Eustace (F.H. 959).

(31) Het treffen was ongemeen hevig: „nos chirurgiens et plusieurs autres de l'escadre sont a penser les blaissés, et tous ceux qu'on a coupés bras ou jambes sont mort peu apres l'operation; nous avons beaucoup de brulés".

(32) F.H. $965-\mathrm{n}^{\circ} 121$ - Certificaat voor bewezen diensten : Nous capitaine des Vaux du Roy - certifions que le nomé Pierre van Atten (sic) qui a opposé avec moy sur le Vaux l'Opiniatre de St. Domingue en France en qualité d'aide-pilote, s'est quité parfaitement bien de ses devoirs et quil ma paru estre au fait de son estat et que i'en ay esté tres contant; que de plus i'en ay esté tres contant dans le combat que nous avons rendu le $218^{\text {bre }} 1757$ à la cotte de St. Domingue, qu'il y a donne des preuves de valeur et bravour pandant le dit combat. A Brest le 27 fevrier 1758. Moëlien. 
nous a l'insu de tout l'Europe" 33 . Onderweg kaapte men een cargo uit New-England, vol kabeljauw. Te Cayes-St.-Louis werden passagiers en lading gelost. De retourvracht ging men, niet zonder moeilijkheden, ophalen te Saint-Louis. Bij de thuisreis praaide de Brocanteur nog twee Engelse vrachtschepen; vrijgegeven tegen losgeld hield men telkens een gijzelaar als waarborg tot de betaling van de wisselbrief. De thuiskomst op 1 juni 1759 verwekte sensatie in het gewurgde Nantes.

\section{De kapiteinscarrière.}

De geïntensifieerde vijandelijkheden ter zee zouden de zeeman aan wal kluisteren tot in de zomer van 1763. Tot werkloosheid gedoemd, „habitué et demeurant ordinairement a Nantes, paroisse de Saint Nicolas" - het financiële hart der havenstad - bezocht hij meermaals de familie Eustace te Ancenis ${ }^{34}$. $\mathrm{Na}$ een succesvolle commerciële come-back had oom Georges zich op een buitengoed op de Loire teruggetrokken.

Tussen zijn zeereizen door had van Alstein zijn praktische ervaring aangevuld met theoretische kennis in het hydrografisch instituut te Nantes, waar ,il s'est tellement appliqué a la connoissance des bancs, courans, marées ecuils, flux et reflux de la mer et variations du compas, meme etudié dans les ecoles de mathematiques..." ${ }^{35}$. Onze toekomstige commandant aspireerde nu naar een kapiteinsbrevet. De toelatingsvoorwaarden leken streng: volgens de Ordonnantie van 15 aug. 1725 waren 10 jaar ervaring op zee ${ }^{36}$ en twee campagnes in dienst der nationale marine vereist. Een koninklijke gunst uit Versailles ontsloeg hem echter van de helft der tweede verplichting wegens zijn heldhaftig gedrag op de Opiniâtre. De proef greep plaats op de zetel der Nantese admiraliteit; als examinatoren fungeerden „,deux anciens maitres, capitains et pilotes de navires", bijgestaan door een ,professeur d'hydrographie en cette ville". De ondervraging teste zowel de theoretische kennis en praktische zeemanservaring, als de verplichtingen van de schipper tegenover de bemanning. Een unaniem gunstige uitspraak promoveerde van Alstein tot gediplomeerd, volwaardig en beëdigd zeekapitein op 28 april 1760. Begonnen als berooid blauwtje vóór 11 jaar, mocht hij zich voortaan „Schipper naast God" noemen. Ondanks

(33) F.H. 968 - Journal du Brocanteur.

(34) F.H. $965-\mathrm{n}^{\circ} 126$ - Met zijn aandeel - demi-profit au Sr Hay - in de opbrengst van 9 dozijn paar schoenen, te Cayes St. Louis verhandeld, kocht van Alstein er o.m. een „ancre de sucre raffiné... donné a ma tante Eustace a Ancenis".

(35) F.H. 963 - Kapiteinsbrevet - In zijn persoonlijk dossier bezat de kapitein een klein register getiteld „Mature et Manoevres", een technische handleiding voor de zeilvaart (F.H. 979).

(36) ibidem - „... lequel nous a declaré qu'il y a plus de dix ans qu'il navigue sur mer en plusieurs voyages de longs cours... faisant ensemble 68 mois, 25 jours...". Zijn steekkaart vermeldde: Montmartel (cap. Bernard Regnier), novigue, 7 okt. 1749-14 nov. 1750, $13 \mathrm{~m}, 7$ d; Montmartel (Jean Gillet), pilotin, 3 apr. 1751-24 juni 1752, $14 \mathrm{~m}, 21 \mathrm{~d}$; Oeconomie (Jerosme Francois Mouton), enseigne, 26 sept. 175210 juli 1754, $21 \mathrm{~m}, 14 \mathrm{~d}$; Mars (Jean Deurbroucq), second-lieutenant, 20 ma. 1755 pris par les Anglois 8 apr. 1756, $12 \mathrm{~m}, 18 \mathrm{~d}$; Brocanteur (Olivier Chaussée), secondcapitaine, 6 nov. $1758-1$ juni $1759,6 \mathrm{~m}, 28 \mathrm{~d}$. Tot aan deze laatste afmonstering was van Alstein dus in totaal slechts 24 maanden aan wal geweest. 
bekrompen financiële middelen en alleen dank zij zijn ijver en doorzettingsvermogen bereikte hij reeds op 26-jarige leeftijd de hoogste graad der zeemansloopbaan.

Eens de vrede getekend (Verdrag van Parijs, feb. 1763) was onze versbakken kapitein er als de kippen bij om met een negercargo in zee te steken. Als tweede-kapitein voer hij op 31 juli 1763 voor rekening van Guillaume Grou ${ }^{37}$ met de Télémaque uit om in Cabinda de reeds eerder uitgelopen Mentor te gaan vervoegen. $\mathrm{Na}$ de veiling der 330 zwarten bleef de kapitein Mathieu Chapeau te Cap-Français achter voor de inning der fondsen, zodat van Alstein, voor de eerste maal als commandant, met de Télémaque op 16 jan. 1765 Paimbœuf binnenvaarde.

De Mentor, die zijn mensenlading naar Cuba gesmokkeld had, liep bij de thuisvaart op de Bretoense klippen onder Phouharnel te pletter. De kostbare lading - campêchehout en een schat van ongeveer 35.000 Spaanse piasters - was reeds door de verzekeraars als verloren opgegeven. In akkoord met G. Grou tekenden ze nochtans een bergingscontract: „... moi, van Alstein je me transporterai au plutot a Plouharnel pour veiller au sauvement des piastres... et feray pour cet effet tous les operations necessaires, ne m'engagant point d'y rester au dela des fetes de Pasques" ${ }^{38}$. Op GoedeVrijdag gebeurde de grote vondst; in totaal groeven de aangeworven kustbewoners gedurende de bergingstermijn uit het slijk op: „20.960 piastres, 2 doubles Louis d'or et un ecus de $3 \mathrm{lb}$ qui font monnoy de france a 5 lb 6s... 109.756 lb." Onze geluksvogel ontving voor zijn wakkere speurzin een verdiend commissieloon.

Kort daarop deed de familiefirma Portier-Frères voor de uitredingstoebereidselen van zijn Africain beroep op P.I.L. van Alstein ${ }^{30}$. De expeditie startte op 25 juni 1766 naar de „Coste d'Angolle”. Een ruime drie maanden volstonden voor de gewiekste ruilhandelaar om te Cabinda het ruim met 386 slaven te vullen. Gemeerd in de rede van Cap-Français slaagde de zakenman er in om, in samenwerking met een locaal commissiehuis, de vracht binnen de 17 dagen te veilen. Om het financieel eindresultaat van deze succesvolle campagne te waarborgen waren de contractanten „... convenus que vous resteriez a St.Domingue pour faire l'eligement de vos credits et recouvrir tous vos termes et payemens pendant l'espace au moins de neuf mois, apres votre navire expedié pour france" ${ }^{40}$. De Africain stevende huiswaarts op 20 mei 1767 ,sous le commandement de mon second". Een jaar later, precies op 1 mei 1768, kwam de kapitein als gewoon passagier thuis.

De reders waren opgetogen over de geslaagde tocht: „Nous soussignés

(37) De reder had vermoedelijk langs zijn vrouw om, Anne O'Shiell - zuster van Marie, echtgenote van A.V. Walsh - het bravourexploot van de Brocanteur gewaardeerd.

(38) F.H. 965 - Het dossier dezer moeilijke onderneming omvat het contract, de onkostenstaat en het proces-verbaal der geborgen munstukken.

(39) Pierre \& Michel Portier de Lantimo; Michel was gehuwd met Marie-Anastasie Walsh, dochter van Patrice en Marie-Anne de Canisburg (Cranisborough).

(40) F.H. $982-\mathrm{n}^{\circ} 12$ - Ordres et Instructions Africain. De documentatie over deze campagne is de meest volledige uit het ganse fonds (boordjournaal, complete boekhouding, facturen) 
reconnoissons que monsieur Pierre van Alstein... s'est comporte dans ce voyage avec tout la prudence et l'equité que nous pouvions esperer d'un aussi galant homme, qu'il nous a rendu des comptes dont nous ne pouvons qu'être satisfaits, et que par reconnoissance nous lui avons confie pour un pareil voyage que celui cy-dessus notre navire le Pompée, a l'armement duquel il est actuellement occupe" ${ }^{41}$.

Deze negercargo verzamelde te Loango 390 zwarten. Door voedselgebrek was men verplicht zich op Saô-Tomé te bevoorraden; terzelfdertijd liet men de mensenlading een opfrissingskuur ondergaan. De Pompée - een oude opgekalefaterde lijnvaarder - werd te Cap-Français afgetakeld. Zoals overeengekomen resideerde P.I.L. opnieuw bijna 15 maand als zakenwaarnemer Pactole te Nantes toe.

$\mathrm{Na}$ zijn terugkeer uit de kolonie, begaf van Alstein zich in de zomer naar Parijs en vandaar naar Vlaanderen, hoogstwaarschijnlijk voor genealogische opsporingen.

In mei 1773 sloot hij met Daniel Garesché, een reder uit La Rochelle, een contract voor een nieuwe slavencampagne ${ }^{42}$. De Duc de Laval kende een bewogen reis: „Traitté a Malimbe environs 400 negres - par la lenteur de la traitte ai été obligé de partir, craignant n'avoir pas assez de vivres pour me rendre a l'Amerique et que le scorbut ne se manifestoit dans ma cargaison ce qui est arrivé en traversée et ai perdu beaucoup de negres et arrivé au Cap demuni de tout vivres pour blanc et negres" 43 . Bij zijn thuiskomst op 27 juni van deze licht deficitaire expeditie rekende van Alstein - die er trouwens voor ft 40.760 in geinteresseerd was - onmiddellijk af en vertrok naar Nantes.

Voorlopig hing hij de zuidwester aan de haak ${ }^{44}$; voortaan zou hij leven van zijn verworven fortuintje dat hij trouwens voortdurend zocht uit te bouwen. Van dec. 1775 af huurde van Alstein te Nantes een kamer en leefde er op vrij brede voet. Aan dit residerend leventje kwam echter een einde in mei 1778 door een reis naar Parijs. In okt. bevond hij zich opnieuw te Nantes, dat hij niet meer zou verlaten vóór mei 1781. Een voorstel om het bevel over een vrachtvaarder naar Isle-de-France (Mauritius) op zich te nemen wees hij beleefd af. De gevaren van de Zeeoorlog (177883) verlokten hem evenmin om dienst te nemen op de Nantese kaperschepen ${ }^{45}$. Omzeggens gans de tweede helft van 1781 en de daaropvolgen-

(41) F.H. 982 - $\mathrm{n}^{\circ} 23^{\mathrm{a}}$ - Opgesteld te Nantes, 24 9bre 1768. De gebroeders Portier deden dit des te liever daar van Alstein voor bijna ft. 12.000 in de campagne investeerde.

(42) F.H. 982 - $\mathrm{n}^{\circ} 72$ - Aanwervingscontract - De Duc de Laval, „... actuellement moüillé devant la ville de Nantes desarmé venant de la Martinique"," was door tussenkomst der gebroeders Montaudoüin aangekocht; van Alstein, die er resideerde, werd ongetwijfeld door deze rederij aanbevolen.

(43) F.H. 969 - Livre de Connaissemens, p. 9.

(44) $\mathrm{Zijn}$ verder curriculum vitae is ons hoofdzakelijk bekend uit een notaboek (F.H. 983 - Livre de Dépenses), waarin van Alstein alle uitgaven minutieus optekende.

(45) „On dit que le commerce de Nantes arme 6 belles fregattes; il faut que cela ne vous tente pas puisque vous ne me marquès point y prendre part. Mandès moi si un commandement de Veau particulier pour transport d'avitaillement a l'isle de france vous conviendroit et si l'occasion se presente de vous en procurer un... je 
de winter reisde hij heen en weer tussen Parijs en de Oostenrijkse Nederlanden. Weer was, naast zakenrelaties, de speurtocht naar afstammingspapieren de hoofddrijfveer voor zijn voortdurende verplaatsingen.

Sedert 1780 hadden de Franse reders een achterpoortje gevonden om ongehinderd hun expedities te organiseren: schepen, onder neutrale vlag uitgereed, ontliepen de Engelse blauw; Oostende en Lissabon werden vrijhavens. $\mathrm{Na}$ een reis naar Bordeaux, sloot van Alstein - officieel nog keizerlijk onderdaan - in dec. 1782 te Nantes door bemiddeling van Desridellières-Leroulx met de Bordelese reders P. Nairac \& fils ainé een overeenkomst af voor hun Pactole, „... actuellement en armement et prêt a partir pour la Cote d'Or sous pavillon imperial, et expedition en consequence, et dans le cas que la Paix se fit avant mon départ de la rivière de Bordeaux, sous pavillon françois..." ${ }^{46}$.Voor de eerste maal in zijn zeemanscarrière zou de Gentenaar nu de Slavenkust aandoen. Als documentatie over deze voor hem nieuwe zeeroute schafte hij zich te Nantes het nodige kaartenmateriaal aan: „1 planc de Bordeaux et instruction (de la Gironde), 1 planc du golphe Biscaye, 1 planc de la coste d'or, 1 planc de variation". Zijn uitrusting vulde hij bij zijn aankomst te Bordeaux aan met ,un noctant anglois en boete, un matelat de mer, un fusil a deux coups" ${ }^{47}$. Deze tweeloop was een voorzorgsmaatregel tegen de weinig vreedzame faam der Guinese inboorlingen.

Via Lissabon, waar een lading Braziliaanse ruiltabak werd ingeslagen, en na een oponthoud te Judas - Ouidah, Frans factorij-fort in Dahomey meerde de Pactole vóór de lagunes van Badagry, nabij het actuele Lagos. De ruiltransacties werden meermaals onderbroken door een stammenoorlog, waaraan P.I.L. persoonlijk deelnam ${ }^{48}$. Bijgewerkt tijdens een verversingskuur op Saô-Tomé, gingen de zwarte koelies te Cap-Français op een maand tijd van de hand. Op 18 sep. 1784, „,.. mon navire charge de sucres, cafe, indigo et piastres; tous mes vivres a bord; ... retire un sac de lettres de la poste", zeilde de cargo huiswaarts. $\mathrm{Na}$ de ontscheping te Pauillac op 20

serois enchanté de vous servir." F.H. 367 - de Montigny du Timeur aan van Alstein ; Parijs, 20 feb. 1779.

(46) F.H. 982, $\mathrm{n}^{\circ} 50-$ Aanwervingscontract (11 dec. 1782). Overhaald door de voordelige bepalingen liet hij de Esperance der rederij Langevin-Frères te Nantes in de steek „... dequel navire j'y ai fait le radoub et ne l'ai voulu commender" (F.H. 978 - Journal de Pactole, 21 juli 1783). Ook deze cargo was voor Guinea bestemd.

(47) F.H. 883 - Cahier de Dépenses.

(48) F.H. 978 - Journal du Pactole - De economische naijver onder de inlandse potentaten $-\ldots .$. ne doutant pas la jalousie de dhahomet de voir tous les navires se fixer a Badagry..." - leidde tot een gewapend conflict; van Alstein steunde het kwetsbare Badagry tegen de gezamenlijke raids van Ardres en Portenove. Als een echte oorlogsreporter signaleerde hij alle gebeurtenissen : „8 aoust 1783 - Les pirogues d'ardre... venoient assez pres pour les canonner et peu a peu ont disparu leurs ayant moi meme tire deux coups a mitrailles en plain de plusieurs pirogues assemblees ; 1 décembre - „les gens de Badagry ont marches avec 4000 hommes... etant bien munis de bonne poudre et balles que je leurs ai fourny ainsy quelques conseils, pendant que je gardois le quartier le plus facil a debarquer avec un vieux canon de six et quatre pierriers d'une livre de balles...; 10 janvier 1874 ... suivant le rapport du capitaine anglois venant de Juda... il se proposent faire un mauvais party de moy disant que j'etois cause de leurs perte dans la derniere affaire et non sans raison...". 
nov., ging P.I.L. te Bordeaux verslag uitbrengen bij Paul Nairac. Samen maakten ze het bilan op ,... le dechargeant de toute comptabilité relative a sa gestion du navire Le Pactolle qu'il vient de comander dans son voiage a la Cote de Guinee" ${ }^{49}$. Zijn eigen sjees, waarmee hij ook naar de Gironde gereisd was, bracht hem op $22 \mathrm{dec}$. uiteindelijk terug in het vertrouwde Nantes.

$\mathrm{Na}$ zeven negercampagnes verspreid over 34 jaren op de cargo's Montmartel, Economie, Mars, Télémaque, Africain, Pompée, Duc de Laval en Pactole, besloot van Alstein definitief een punt te zetten achter zijn loopbaan als kapitein op de driehoeksvaart. Tijdens zijn maandenlange zeereizen had onze globetrotter de halve wereld gezien: 7 tochten naar de "Coste d'Angolle" 50 (Malimbe: 3; Loango: 2; Cabinda: 2); 1 campagne op de Slavenkust; sporadisch aanleggen op de eilanden der Golf van Guinea (Saô-Tomé, Principe, Annabon); verblijven op Haïti (Cap-Français: 7; Cayes-St. Louis: 2) ; een jaar krijgsgevangenschap op Jamaïca en oponthouden te Martinique en Lissabon. Voortaan beschikte hij over ruim voldoende inkomsten om het renteniersleven van de hoge Nantese burgerij te delen, waar we hem in een verdere rubriek zullen terugvinden.

C.

DE OPBOUW VAN EEN FORTUIN.

\section{De Verdiensten der Driehoeksvaart.}

a) Vergoedingen inherent aan de campagnes.

Daar waar de gewone matroos alleen op een maandwedde mocht rekenen, waren de leden van de staf meer begunstigd. Immers het reusachtige kapitaal in de campagne geïnvesteerd lag volledig in hun handen. De reders hadden dan ook alle reden om zich van de goede trouw en inspanningen der officieren te verzekeren door hen, buiten hun gage, andere voordelen toe te kennen.

Aangeworven voor zijn "maidentrip" op de Montmartel zonder soldij, bofte van Alstein toch nog dat hij niet als scheepsjongen meemoest; zijn voorgelogen 18 jaar bezorgde hem het gunstiger baantje van „novice”. Zijn eerste salaris van ft 24 per maand, ontving hij als "pilotin" tijdens de volgende tocht met dezelfde cargo. Onze „enseigne” op de Economie verdiende reeds $\mathrm{ft}$. $36 /$ maand. Nergens echter vonden we een spoor van zijn

(49) F.H. $982-n^{\circ} 49$ - Lopende rekening Nairac-Van Alstein (6 dec. 1784). (50) In de slavenmiddens verstond men hieronder de kustzone benoorden en bezuiden de Zaïre (Congostroom), van Kaap Lopez tot de baai van Ambriz (Portugees Angola). Met de verkeerde benaming "Coste d'Or" of het vage "Guinée" bedoelde men in feite de Slavenkust (tussen Volta-rivier en Kaap Lagos) en de Golf van Benin. 
bezoldiging als „second-lieutenant et ecrivain" van de Mars. Nochtans als Britse krijgsgevangenen ,nous fumes taxés aux payes suivantes par 8 jours: ... second lieutenant 24 escalins ou 18 francs." Wat van Alstein kon sparen op Jamaïca en bij de marine op Haiti verdween echter in de schipbreuk van de Opiniâtre vóór Brest waarbij „... tout le monde se sauve... j'y ai perdu mon coffre"; meer nog, de ft. 151 ( $£$ t. 30/maand) soldij die de admiraliteit hem bij de afmonstering nog schuldig was, kreeg hij nooit los.

De tweede-kapitein van de lijnvaarder-kaper Brocanteur inkasseerde reeds een maandwedde van ft. 65. Alhoewel hij nochtans dezelfde post bekleedde bezorgde de Télémaque hem ft. 80; zijn kapiteinsbrevet en de driehoekscampagne waren daar zeker niet vreemd aan. De reders garandeerden voor de Africain- en Pompée-expédities „... vos gages de cap ${ }^{n e}$ de 150 livres par mois que nous vous payerons en france, tant pendant votre voyage, que pendant le tems de votre sejour a St. Dominique et qui enfin ne cesseront que le jour que vous debarquerez en france..." ${ }^{\text {s1. Contrac- }}$ tueel voorzag de Duc de Laval hetzelfde loon. Tenslotte, om van Alstein naar Bordeaux te krijgen keerde de rederij van de Pactole zelfs de dubbele gage van $\mathrm{ft}$. 300 uit ${ }^{52}$.

Voor hun ijver bij ruilverrichtingen en negerveiling genoten de gezagvoerder en zijn naaste ondergeschikten in de regel een provisie. Te CapFrançais ontving van Alstein, 2de in bevel op de Télémaque, „pour sa commission... 10 livres par tête de 330 negres vendus" ${ }^{53}$. Voor de vier daaropvolgende slavencampagnes die P.I.L. als bevelvoerend kapitein leidde, genoot hij telkens „... tant pour vos peines et soins pendant la taitte que vous ferez à la cote de Guinée, que de la vente de la ditte cargaison a St. Domingue, une commission de $5 \%$ sur le montant total de la vente...". Daarenboven beloofden de reders van Africain en Pompée „... de plus $2 \%$ de commission sur tous les retours generalement quelconques de recouvrement des credits que vous nous ferez..." 54. Daarbij kwam nog dat hij zich $5 \%$ reserveerde bij de sloping van de Pompée.

De voornaamste officieren mochten veelal voor eigen rekening ruilwaar gratis aan boord brengen (pacotille) om zich hiermee negerslaven aan te schaffen die vrachtvrij (port-permis) de overtocht meemaakten. Voor een "pacotille" bestaande uit 20 guaras (textiel ter waarde van ft. 375), ruilde van Alstein twee robuste jonge negers, die echter samen met de Mars te Kingston terecht kwamen. Bij de Pactole-campagne kreeg hij o.m. recht

(51) F.H. $982-\mathrm{n}^{\text {0 }} 12,17$ - Ordres en Instructions Afriquain-Pompée.

(52) F.H. 982, $\mathrm{n}^{\circ} 50$ - Contract - Dit buitengewoon hoog zeemansloon is te verklaren door een nijpend gebrek aan kapiteins na de Zeeoorlog, wanneer daarenboven voor de slavenhandel een echte "boom" aanbrak. De firma Nairac fraudeerde daarbij in de "fiscale" bijdrage voor de "Caisse des Invalides" door de afhouding slecht op ft. 200 te berekenen. (F.H. 982, $n^{\circ} 49$ ).

(53) F.H. $965-\mathrm{f}^{\circ} 93 \mathrm{v}^{\circ}$ - Alle vergoedingen in de kolonie uitgekeerd i.v.m. slavenveilingen en retourladingen werden, zoals de transacties, berekend in livres coloniales (symbool fc.). Dit "livre argent de l'Amérique" bezat een minderwaarde van $1 / 3$ t.o.v. het moederlandse "livre tournois"; dus $100 \mathrm{fc}=662 / 3 \mathrm{f}$.

(54) F.H. 982, $\mathrm{n}^{\text {0ะ }} 12,17$; Deze dubbele provisie werd gecombineerd : „ainsi vous passerez pour le premier objet et pour le second $7 \%$ de commission dans vos factures de chargement que vous ferez par vous mêmes pendant le tems que vous resterez a St. Domingue...". 
VERDIENSTEN DER NEGERCAMPAGNES

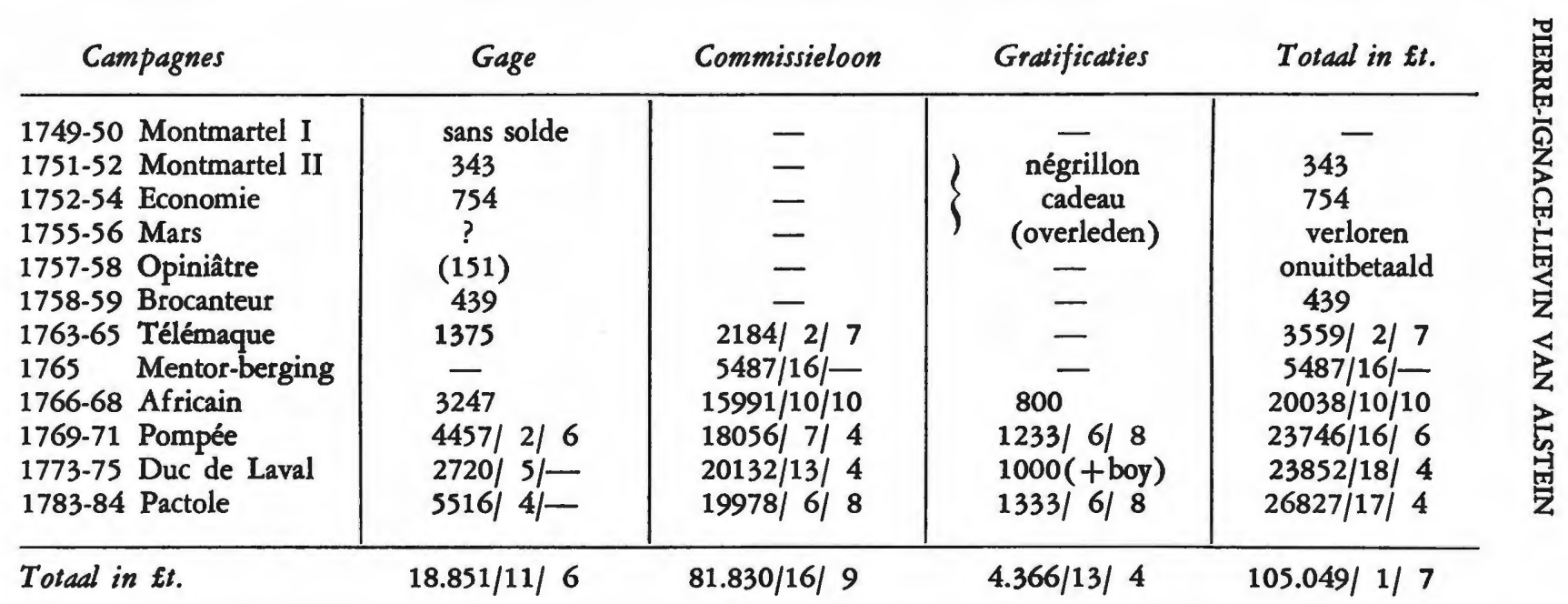


zowel op een koppel nègres-de-pacotille ${ }^{55}$ als op „60 quintaux de portpermis en retour de St. Domingue en France", d.w.z. vrachtvrijstelling voor $6.000 \mathrm{lb}$. ( $\pm 2.935 \mathrm{~kg}$.) retourvracht. Traditioneel stond de rederij aan de commandant daarenboven de keuze toe van ,... un négrillon de l'age de 10 a 12 ans pour vous servir de domestique dont nous vous faisons present...". Gewoonlijk werd deze knaap dan samen met zijn overige lotgenoten geveild. Op de Duc de Laval echter bracht van Alstein hem als zijn boy mee naar Nantes. Uitzonderlijk verschafte deze laatste campagne nog een extra-beloning van ft. 1.000 ,pour la gratification convenuë sur la masse de ses retours par son navire quoiqu'elle ne s'eleve point a la somme prescrite" 56 .

Wat vertegenwoordigden nu financieel deze cumulaties van gages, commissielonen en overige individuele voordelen? De naakte cijfers uit de voorafgaande tabel spreken klare taal ${ }^{57}$. Eens kapitein gingen de verdiensten pijlsnel omhoog. De laatste vier campagnes verzekerden zelfs een doorsnee-inkomen van gemiddeld ft. 23.600! Doch hierbij bleven de opbrengsten allerminst beperkt zoals aanstonds blijken zal.

\section{b) Investeringen in expedities.}

Zodra van Alstein over voldoende fondsen beschikte participeerde hij in diverse campagnes teneinde de vruchten van zijn eigen inspanningen gedeeltelijk zelf te plukken. Aangezien de commerciële verrichtingen van de Africain hem een flinke ft. 20.000 hadden opgebracht, verleenden Portier-Frères graag ,... un seizieme d'interest que nous lui avons cedé dans le navire le Pompée quil doit commander...", temeer dat dit zijn zorg voor de goede afloop nog zou stimuleren. De ,2/32 d'interest... dans l'entière expedition" bedroegen $\mathrm{ft}$. $11.757 / 14 / 3$; zijn dividenden - waarvan de uitkeringen echter aansleepten tot nov. 1792 - beliepen in totaal ft. $14.655 / 1 / 4$. Rekening gehouden met de assurantiepremies voor de retourzendingen, stak van Alstein uiteindelijk ft. 2.603/2/7 op, hetzij 21,6\% van het geïnvesteerd kapitaal 58 .

In de Duc de Laval belegde P.I.L. zelfs $1 / 8$, hetzij ft. 40.760/1/3. Geleerd door ervaring, nam hij echter voorzorgen tegen een vermoedelijke krach, die de Zeeoorlog inderdaad zou meebrengen „... en me reservant la faculté de ceder et transporter a $\mathrm{M}^{\mathrm{r}} \mathrm{Dl}$. Gareché mon huit d'interest dans les fonds et creances que le navire laissera apres luy à l'amerique sur

(55) F.H. $982 ; n^{\circ} 50$ - (Contract) - ,deux negres que je pourrai traitter à la Côte et embarquer dans le navire gratis de fret, parce que j'aurai la liberté d'emporter ce qui sera necessaire pour les traitter et rien de plus". Hiervoor kocht P.I.L. te Lissabon 20 rollen tabak voor Et. 858/11/6 (F.H. 982; 15).

(56) F.H. $982 ; \mathrm{n}^{\circ} 66-$ (Lop. rek.). Het aanwervingscontract voorzag immers ,une gratification de $£ 1.000$ argent de france autant que la remise en retour par son navire s'elevera a $£ 300.000$ argent de l'Amerique...",

(57) Voor de opstelling benutten we elementen uit facturen, rekeningsuittreksels en lopende rekeningen. Alle gegevens waren uitgedrukt of werden omgerekend in ft.

(58) F.H. $982 ; n^{\circ} 23$ (Compte rendu aux co-intéressés); F.H. suppl. 56 (private boekhouding) : montant de $2 / 32$ d'interest...; rentrée des fonds de mes $2 / 32$ d'interest... 
le pied de $50 \%$ de perte..." 59. De afrekening op basis van deze clausule gaf wel als boni ft. 1.098/9/11, doch na aftrok der verzekeringspremie van Alstein behartigde uitzonderlijk „... sa propre affaire des assurances de son interêt" - bleef nochtans een deficiet over van ft. 2.162/6/1 ${ }^{60}$.

Voorzichtiger geworden, belegde hij in de Pactole nauwelijks een minieme ft. 6.000. De verzekering echter, die hij slechts afsloot „pour la Coste d'Or et a L'amerique" laat eerder vermoeden dat dit geen zuivere participatie betrof, doch hoogstwaarschijnlijk alleen een private transactie onder vorm van toegestane pacotille en enkele slaven voor eigen rekening verscheept.

\section{c) Voordelen der neventransacties.}

Doorgaans zette de kapitein zijn op Haïti voor eigen rekening verworven bedragen ter plaats om in natura of vreemde speciën ${ }^{61}$. De koloniale produkten of zakken geld vonden dan te Nantes door tussenkomst van een zaakwaarnemer afzet. Op een retourlading van „...13 barriques de sucre terré et têtez... provenants de ma commission de vente et recouvrement des fonds de l'Afriquain..." stak de kapitein ft. 540 op. Twee zendingen, tijdens de Pompée-campagne overgezonden, beliepen in totaal „22 barriques de sucre terré (cassonade); 11 boucauts, 1 barrique de caffé; 3 dents de mophil" (ivoor in Afrika geruild); de nettowinst beliep ft. 1.285/2. Terwijl de Pactole nog op Haiti vertoefde, kwamen eveneens 15 olifantstanden te Nantes aan; ze gingen er van de hand voor ft. $497 / 6 / 6$ - de aankoopwaarde is onbekend - Alleen een „4.000 piastres gourdes et 30 ecus", aangekocht te Cap-Français in 1784, verloren Lt. $980 / 7 / 6$ aan verkoopwaarde.

Tenslotte fungeerde van Alstein een paar maal als koloniaal verkoopsagent voor uit het moederland toegezonden of meegevoerde waren. Een gemende zending (textiel, bier, bouwmaterialen, vaatwerk) door Portier de Lantimo Fils en twee bedienden der rederij geconsigneerd „... a l'adresse de Van Alstein, actuellement au Cap pour en faire la vente la plus avantageuse..." bezorgde hem aldus ft. 186/13 verkoopsprovisie. Toen de Brocanteur in volle oorlogscrisis Cayes-St. Louis bevoorraadde, versjacherde P.I.L. er een "pacotille a demie profit" van 9 dozijn paar schoenen. Zijn helft der verkoopsom (netto-winst ft. 301/6) zette hij om in indigo en suiker die hem te Nantes een woekerwinst van ft. 511/1/5 verzekerden; in totaal dus een beneficie van ft. 802/6/5 ${ }^{82}$. Pas 25 jaar, verdiende de

(59) F.H. $982 ; \mathrm{n}^{\circ} 72-\mathrm{Bij}$ de ondertekening van dit contract (28 mei 1773) bleven van de vorige Pompée-campagne nog voor ft 125.856/12 aan achterstallige fondsen te innen (id. $\mathrm{n}^{\circ} 62$ ). Op 15 nov. 1792, midden de bloedige rassenonlusten op Haïti, moesten er nog ft $32.848 / 4$ binnenkomen.

(60) F.H. $982 ; n^{\circ} 71$ (Compte du retour). Zijn private boekhouding vermeldde ",assurance... pendant tout le voyage a $8 \mathrm{pCt}: \mathrm{ft} 3.260 / 16$ ".

(61) Daar het koloniale pond een rekenmunt was waarvoor de metropool nooit een equivalent had geslagen, dienden zijn inkomsten van commissielonen en andere gratificaties door het commissiehuis of door de kapitein zelf, hetzij via scriptair geld en lopende rekeningen, hetzij in Spaanse munten te worden vereffend.

(62) F.H. $982 ; n^{\circ *} 41,36 ; 37 ; 47,51$ à 53 en F.H. 965, f $^{\circ *} 114$ à 116, 123 à 126 (verkooprekeningen). 
toenmalige tweede-kapitein met dit zaakje het dubbele van zijn gage! Rekening gehouden met alle voorafgaande verdiensten, winsten als verliezen inbegrepen, bezorgden vier neger-campagnes, verspreid over ruim 18 jaren (1766-84) een minimum globaal-inkomen van $\mathrm{ft.} 95.938 / 7 / 4^{63}$, d.w.z. in doorsnee een jaarlijks gemiddelde van rond de ft. 6.000 .

\section{2. "Financial Business” te Nantes.}

\section{a) Financieel beheer.}

Ofschoon P.I.L. van Alstein de bouwstenen van zijn toekomstig fortuin in hoofdzaak langzamerhand verzamelde langsheen de driehoeksroute, zocht hij niettemin tussen de campagnes door voortdurend zijn kapitaal uit te bouwen in ondernemingen die totaal vreemd waren aan de driehoekshandel. Als minutieus en ervaren zakenman verwaarloosde hij daarbij geenszins een efficiënt beheer. In een lijvig register centraliseerde de kapitein overzichtelijk alle ondernemingen, leningen, speculaties, erfenissen en eigendommen waarbij zijn kapitaal te pas $\mathrm{kwam}$. Zijn dagelijkse uitgaven noteerde hij scrupuleus in een handig, in perkament gebonden dagboek van klein formaat dat hem overal vergezelde ${ }^{64}$. Alle rekeninguittreksels en facturen ploos hij persoonlijk zorgvuldig uit. Zo stond hij er op dat hem nog ft. 239/17 meer toekwamen dan de afrekening van de Duc de Laval aangaf ${ }^{65}$. Hardnekkig liep hij alles wat hem toebehoorde na. Een staaltje van deze financiële onverzettelijkheid gaf van Alstein toen hij in april 1781 an een kennis opdroeg om in Brest ,vouloir soliciter et recevoir le payement de la somme (ft. 151) ... dont je n'ai pu estre payé". Het betrof hier de achterstallige gage van de Opiniâtre uit maart 1758 !! 66 .

Tijdens zijn afwezigheden behartigden Nantese zaakwaarnemers zijn belangen. Tussen 1763-72 bleef dit Luc-Nicolaas O'Shiell, schoonbroer van G. Grou, reder der Télémaque; dezelfde negociant verzorgde eveneens de afzet der particuliere retourzendingen voor van Alsteins rekening aan een gratis commissieloon. Nadien droeg P.I.L. deze taak op an de firma Mon-

(63) Africain : ft 20.765/3/10 ; Pompée : ft 27.635/1/1 ; Duc de Laval ft $21.690 /$ 12/3 ; Pactole : ft 25.847/9/10; bij deze laatste expeditie kwamen dan nog eens de opbrengsten van 2 pacotille-negers, 15 olifantstanden en 60 quintalen retourwaren.

(64) F.H. suppl. $56-\mathrm{Zijn}$ private boekhouding $-{ }_{,} \mathbf{N}^{\circ} 1$, Livre et papiers de la succession de Pierre-Lévin-Ignace Van Alstein à la disposition de son frere et seul heritier Louis-Grégoire Van Alstein... (doorgeschrapte titel van vreemde hand) is fragmentair, gelukkig slechts i.v.m. de leningen.

F.H. 983 - Livre de Dépenses journalières depuis Juillet 1775 jusqu'au mois sept. $1787-\mathbf{N}^{\circ} 1$. Het vervolg $\left(\mathbf{N}^{\circ} 2\right)$ ging vermoedelijk verloren in de warboel der Revolutie.

(65) F.H. $982 ; n^{\circ} 64-$ D. Garesché willigde de eis in ; ondanks „... le sac de $1000 \mathrm{lb}$ que je vous ai alloüé sans qu'il vous fut dû... je veux finir avec vous comme j'ai commencé par de bons procedés. Faites fraite sur moi..." (La Rocheile, 4 apr. 1776).

(66) F.H. 965 ; n 121 - (rugzijde licentie) - Mr. de Segonsac kreeg alleen te horen dat „.... cette somme n'ayant pas éte reclamée, a eté versée... dans la caisse des Invalides... On ne peut l'en retirer que par ordre du Roy". (Brest, 25 mei 1781 - F.H. 367). 
taudoüin-Frères. Tenslotte, sedert juli 1779 deed hij beroep op J. Kelly, „negociant sur la Fosse (rederskwartier), rue de Gorge”.

b) Investeringen, speculaties en occasionele handel.

Tijdens de Amerikaanse Vrijheidsoorlog zond de Nantese rederij Charette \& Ozenne in dec. 1777 uit St. Malo een zwaarbewapend fregat naar New-England, om als smokkelschip de opstandelingen te bevoorraden. Bedrogen door een tabaksplanter uit North-Carolina, keerde de Pallas slechts met 100 balen retourlading van Cap-Lookout terug. Als dividend voor zijn ingetekende ft. 3.000 keerde de rederij in juni 1779 nauwelijks ft. $3.121 / 8$ uit; van Alstein stak er bijgevolg ft. $1.678 / 12$ in „\#. a cause de l'assurance d'aller et venir à L'amerique angloise... de plus forte somme de 4.500 lb. a $40 \%$ " ${ }^{87}$.

Wanneer in 1778 te Parijs de commanditaire vennootschap Perrier-Frères et $\mathrm{C}^{10}$ voor de aanleg van een waterverdelingsnet werd opgericht, kocht van Alstein 10 aandelen van ft. 1.200 elk, die jaarlijks $5 \%$ intrest op de intekensom waarborgden. Het jaar daarop liet hij ze reeds over aan zijn medeaandeelhouder tegen de nominale waarde, aangezien hij oordeelde dat de oorlogsomstandigheden het welslagen der onderneming in het gedrang brachten: „Cette entreprise, vu le tems de guerre, trennant un peu en longueur et m'en a dégoutté, ... de sorte que Mr. de Montigny du Timeur (de Paris) a bien voulu reprendre pour son compte et risques... ces 10 actions..." 68 .

$\mathrm{Na}$ zijn mislukking in deze beide investeringen, waagde van Alstein zich aan grondspeculaties. In 1787 associeerde hij zich met de ingenieur Jacobsen de la Crosniere voor de drooglegging van schorren. Mits ft. 4.500 nam hij de helft over der concessie bestaande uit vier „delais de mer" gelegen op het eiland Noirmoutier en langsheen de kuststrook genaamd Notre-Dame de Mont (grondgebied van Nre Dame de Beauvoirsur-Mer). Toen de werken reeds voor zijn rekening ft. 4.250 hadden opgeslokt, gaf onze oud-kapitein de brui aan de te riskante en weinig renderende onderneming: „,... il préferait renoncer à la chose que de risquer sa fortune qui lui avait coûté 40 ans de travail..." ${ }^{60}$.

In belastingsverpachtingen der provincie Bretagne liet van Alstein, via Montaudoüin-Frères en onder de schuilnaam Beconois, ft. 12.500 beleg-

(67) F.H. 982, $\mathrm{n}^{\circ} 13$; F.H. suppl. 56, f० $15 \mathrm{v}^{\circ}$; F.H. 983.

(68) F.H. 367 - Project de la Société des Eaux; F.H. suppl. 56, fo $11 \mathrm{v}^{\circ}-$ Door deze acties vroegtijdig te liquideren verkeek Alstein een mooie winstkans : in dec. 1786 was de koers gestegen tot ft 3.120 ; hij daalde tot 2.560 in maart 1787 (F.H. 986).

(69) F.H. suppl.. 56, f 19 - F.H. 346, Jacobsen aan Joseph van Alstein (Nantes, 19 okt. 1796) : „Comme j'étais très lié avec lui, qu'il avait des fonds à placer, il me pria de lui ceder la moitié d'une concession... sur la proposition... de faire l'avance de tous les fonds pour telle entreprise qui devait coûter 160 mille livres... J'avais déjà fait des desiechements semblables et comme nous n'avions que six ans pour l'encloture... je fis mes préparatifs de consequence... et j'avais déjà commencé et dépensé plus de douze mille livres lorsque notre ami Van-alstein arrêtta tous les travaux par son indécision; ... il fallait attendre des tems plus heureux". 
gen voor de inningstermijn 1775-76. Daar de belastingsomslag hem proportioneel slechts ft. 12.125 opleverde, liet hij zijn hernieuwde inschrijving verder lopen voor de periode $1777-78$ en verdubbelde het ingelegde kapitaal zelfs tot $\mathrm{ft}$. 25.000. Deze dividenden beliepen in $1780 \mathrm{reeds} \mathrm{ft}$. 27.375. Gesoldeerd in ma. 1792 bedroeg de totale eindwinst ft. $2.250^{70}$.

Regelmatig schafte van Alstein zich, in gezamenlijke rekening met de echtgenote van zijn zaakwaarnemer Luc O'Shiell - Marie Clarke - biljetten aan der Hollandse Staatsloterij via Henry Castaing, O'Shiells agent te Amsterdam. Na een zevental trekkingen tussen 1765-71 staken ze er elk ft. 190 aan toe. In jan. 1776 bestelde hij zijn zijn kozijns Edward \& Jacques Gough te Cadix loterijbiljetten, uitgegeven zogezegd ter financiering van het Murciakanaal, ter waarde van Lt. 1.215/5. De winnende nummers ontvingen een kleine lijfrente die echter in dec. 1791 geannuleerd werd „en payant seulement cinq années desdittes rentes pour solde de toutte pretention". De ganse zaak had uiteindelijk ft. 486/13 winst opgeleverd ${ }^{71}$.

Kort na de Pactole-campagne, consigneerde hij aan een Bordelese vriend $161 / 2$ dozijn paar witte en gekleurde kousen. Verkocht aan vrienden en kennissen, bedroeg de verkoopfactuur ft. $576^{72}$.

\section{c) Leningen.}

Nadat in feb. 1776 Daniel Garesché de rekeningen voor de Duc de Laval afsloot en zijn laatste remises aan van Alstein overmaakte, beschikte de kapitein virtueel over een kapitaal van om en bij de $£$ t. $60.000^{73}$. Financieel op het droge liet hij voorlopig de driehoeksvaart links liggen en zocht als geldschieter zijn fondsen te doen renderen.

$\mathrm{Bij}$ twee leningen op korte termijn door de firma Montaudoüin aan de Nantese textielmanufactuur Kuster \& Peloutier toegestaan was van Alstein respectievelijk voor ft. 22.276 (1772-73) en 13.765 (1774-75) betrokken; zijn intrest à $5 \%$ beliep in totaal ft. 1.499/2 ${ }^{74}$.

Op het einde van het Oud-Regiem en in de moeilijke beginjaren der Revolutie schoot hij, door tussenkomst van zijn vroegere zaakwaarnemer O'Shiell, vaak aanzienlijke bedragen - schommelend tussen ft 10.000 en 19.000 - voor aan Nantese firma's: Drouet-Frères, negotianten uit een oud redersgeslacht, in 1778 tijdelijk zijn zaakwaarnemers; Vandamme, Terrijn \& Lenssens: Jean-Baptiste Vandamme, Gentenaar van geboorte, zal na van Alsteins dood diens erfenis behartigen; de kleine rederij Dom. Deurbroucq \& Fils; Arthur Montaudoüin — zijn broer-vennoot overleed

(70) F.H. suppl. 56 ; f f $^{\circ} 13$; F.H. $982, \mathrm{n}^{\circ} 38$. Ondanks deze voordelige omslag waagde van Alstein geen nieuwe investering daar ,... les nouveaux fermiers ayent payé plus cher et se trouvent par la guere en position plus desavantageuse..." (F.H. 367 - de Montigne du Timeur aan P.I.L. - Parijs, 20 feb. 1779).

(71) F.H. 982, $\mathbf{n}^{\circ 2} 56,57-$ F.H. suppl. 56, fos $16,17$.

(72) F.H. 982, $n^{\circ} 58-\mathrm{J}$. Carlié aan Van Alstein (Bordeaux, $15 \mathrm{ma} .1786$ ).

(73) De toenmalige globale inkomsten (ft 79.820) dienen met ft 20.187 verminderd te worden voor uitgaven gedurende de periode 1748-75 (F.H. suppl. 56).

(74) F.H. 982, $\mathrm{n}^{\circ} 38$. 
in 1781; Charette en Chanceaulme-Frères. Verder verleende van Alstein steun aan kennissen en verre familieleden, doorgaans edellieden of exreders die in de adel waren opgegaan en die meestal te Nantes resideerden: Pierre F. de Bardon, oud-scheepskapitein, burggraaf van Segonsac (Cognac) en Anne de Stapleton, zijn echtgenote, dochter van Agnes O'Shiell ; zijn zwager markies J.Bapt. de Laurens, gehuwd met Marie de Stapleton ; haar broer Luc-Edmond de Stapleton, graaf van Trèves (Gennes); Antoine Walsh (zoon van Antoine Vincent), burggraaf en regimentskolonel, en diens echtgenote Marie de Serrant; Ferron de la Ferronnais en zijn vrouw A.P. Fournier; Montaudoüin de la Source (buitengoed nabij Orleans); Joulin, oud-koloniaal uit St. Domingue; tenslotte aan zijn oudvennoot Jacobsen uit Noirmoutier en Dachon, schoonzoon van zijn tante Eustace.

Deze financiële activiteit intensifieerde zich vooral in de eerste jaren der Revolutie. De afschaffing der heerlijke privileges, gesequestreerde goederen en jacqueries stelden de adel voor zware problemen. In de zomer van 1792 berekende van Alstein dat het uitgeleende kapitaal voor een totaal van ft. $88.302 / 14$ uiterlijk binnen anderhalf jaar ft. $4.294 / 16$ aan intrest zou opleveren ${ }^{75}$.

Dank zij deze financiële staat en posthume nasporingen door de erfgenamen verricht, kennen we de voornaamste dubieuze schuldenaars en hun verder wedervaren. Luc de Stapleton ( $£$ t. $45.063 / 15$ schuldig in juli 1793) „... n'a point emigré, mais il a trois fils qui les sont, ce qui retient ses biens en sequestre; ce particulier neanmoins est très riche en biens fonds...". De gezusters Stapleton de Segonsac en Stapleton de Laurens (elk ft. 6.300 in juni 1793) „...sont solides en biens fonds, mais aussi nullement dans le cas de pouvoir rembourser". Montaudoüin de la Source (£t. $12.924 / 12$ in jan. 1794) „... reconnu riche en biens fonds en France et non émigré. Il habite une de ses terres..." De insolvente F. de la Ferronnays (ft. 11.500) „... absolument emigré des le commencement de la Revolution..., ses biens sequestrés et confisques au profit de la nation..."; A. Montaudoüin de Launay - „... très riche en biens fonds et creances en Amérique, a fait des pertes enormes..." - die zich voor de edelman had borg gesteld overleed in 1793. Onvoorzichtig genoeg had van Alstein aan de reeds naar Brussel uitgeweken Walsh de Serrant in dec. $1791 \mathrm{nog} \mathrm{ft}$. 4.400 geleend. Alleen Jacobsen (ft. 4.901/19) en Dachon (ft. 987/4) betaalden hun schulden ${ }^{76}$.

Deze leningen liepen doorgaans over 6 maand of 1 jaar tegen $5 \%$ intrest. In ruil ontving van Alstein schuld- of wisselbrieven, waarvan de op de vervaldag te betalen waarden het geleende kapitaal vermeerderd met de intrest omvatten.

Verder speculeerde hij soms op de assignatenkoers: alhoewel zijn geleende sommen in goud of zilver waren neergeteld, aanvaardde hij enige

(75) F.H. suppl. 56, fos 1 à 8 ; F.H. 366 - Copie du relevé (8 aug. 1792).

(76) F.H. 366 - J.B. Van Damme aan Joseph vn Alstein (Nantes, 7 brumaire, Se an - 28 okt. 1796). In sept. 1797 informeerde J. van Alstein nog bij O'Shiell die de familiezaken der Stapeltons beheerde - naar de vereffening der ft 57.663 schulden (F.H. 361). 
malen de schulddelging in assignaten, mits natuurlijk een flink agio. Zo betaalde de rederij Riedy \& Thurninger hem als opgeld $25 \%$ hetzij $\mathrm{ft}$. $3.292 / 15$ in assignaten. Hij zelf wisselde dan het papiergeld uit tegen klinkende munt met slechts $5 \%$ disconto.

Uit deze eerder droge opsomming komt van Alstein als een uiterst gewiekst en energiek zakenman naar voor. Gebruik makend van alle kansen die de tijdsomstandigheden verleenden en dank zij veelzijdige en weldoordachte beleggingen - die weliswaar niet altijd succesvol uitvielen bouwde hij zijn fortuin uit door onophoudelijk rendement. Zijn menigvuldige en voorname zakenrelaties bewijzen de aanzienlijke financiële positie en de hoge standing waarop hij kon bogen. Juist geteld op 17 jaar boekte hij een ,recette generalle de l'interet de mon argent depuis $1775^{\prime \prime}$ van ft. 116.269/16/3., met als topjaar 1792; het jaar vóór zijn dramatisch overlijden inkasseerde hij nog ft. 12.627.

\section{Erfenissen.}

Tenslotte vielen van Alstein een paar erfenissen te beurt. In 1762 liet Jeanne-Anne D'hamere - een achterkleindochter van zijn overgrootmoeder langs vaderszijde - enkele leengoederen na, gelegen te Bachte, Vosselare en Poncquet (Poeke of Poesele?) Zijn deel in de verkoopopbrengst bedroeg ft. 356/8/2 vlaams wisselgeld; omgezet in Franse munt ft. 4.411/4/3. Als erfgenaam van Marie Meys - kleindochter van een groottante langs vaderszijde en gehuwd met de ontvanger van het land van Dendermonde - remitteerde men hem uit Vlaanderen in 1776 en de daaropvolgende jaren ft. 5.787/10/2. Vader van Alstein bezat een rentbrief van fl. 3.110/17/9 op de belastingen van het Gents kwartier. De jaarrente van $£ 20 / 17$ groot (ongeveer $5 \%$ ) was echter toegewezen aan zijn zoon Louis-Gregoire bij zijn priesterkeuze. Toen echter in 1782 de rentbrief werd terugbetaald ontving P.I.L. 1/3 als erfdeel (£t. 2.222/2). Zijn in 1769 overleden oom Jean-Baptiste Gough, in leven kanunnik te Ieper, liet twee aandelen na van ft. 500 elk a $5 \%$ in de Compagnie des Indes; van Alstein erfde een kwart dat hem tijdens 1772-92, na $10 \%$ voorheffing, nog ft. 260/0/6 opbracht. De van Alsteins bezaten een dagwand land, waarop naderhand een hoeve was opgericht. Dit pachtgoed gelegen op St.-Pieters-Aelst buiten de Kortrijkse Poort in de Galgenstraat, bracht jaarlijks $£ 12$ vlaams op. In 1791 remitteerde pastoor Louis-Grégoire aan zijn broer in twee wisselbrieven ft. 4.466/10,,a compte de ce qu'il a recu depuis ans... de nos rentes tant en flandre qu'en france". De herkomst van deze renten is echter niet duidelijk. Van de lijfrente van ft. 1.200 a $9 \%$ in 1781 door de priester aangekocht „,... sur sa tete et en survivance sur la mienne..." genoot P.I.L. echter nooit vermits hij eerst overleed ${ }^{77}$.

(77) F.H. suppl. 56, passim. Wisselkoers : $\mathrm{ft} 90=\mathrm{ffB}^{\circ} 42=6 £$ vlaems wisselgelt. 
D.

SOCIAAL PORTRET VAN EEN „NOUVEAU RICHE”.

\section{De levenswijze van een "bourgeois-gentilbomme"}

a) Verblijf in de kolonie.

Parallel met zijn financiële aspiraties waakte van Alstein er steeds zorgvuldig over om zich door gedrag, omgang en uiterlijk van zijn ondergeschikten te onderscheiden en overeenkomstig zijn stand te leven. Als Brits krijgsgevangene op Jamaïca ondertekende de jonge luitenant zonder schroom het collectief verzoekschrift „,... afin de nous vouloir ceparer de parmis les matelots en luy disant que nous n'etions pas accutumé d'etre compromis avec ces sortes de gens". Te Spanishtown kon hij vanwege de provoost vlug een appartement loskrijgen en deelde dit met vijf persoonlijk uitgezochte lotgenoten. De geïnterneerden deden er zich allerminst te kort „... car le Roy payoit tout".

In juli 1757 weigerde hij kordaat op Haiti gewone matroos te spelen aan boord van de cargo Achille, vooraleer als hulpstuurman op de Opiniâtre aan te monsteren ${ }^{78}$. Onze tweede-kapitein zorgde er voor dat de officierendis van de Télémaque te Cap-Français steeds goed voorzien was van Bordeaux-wijn en fijne hapjes.

Contractueel had van Alstein er zich toe verbonden na de afvaart van zijn Africain nog negen maanden op Saint-Domingue te blijven. Als vergoeding stond de rederij toe dat ,... à l'egard de votre nourriture, pension, logement et autre petits frais ... vous les passiez dans le compte des autres frais ... sur pied de 200 livres par mois argent de l'amerique...". De Gentenaar huurde er een gemeubileerde kamer met volledig pension aan $180 \mathrm{fc}$ per maand; dit hoge tarief - slecht $30 \mathrm{ft}$ betaalde hij te Nantes! - verzekerde hem echter een confortabel verblijf. Uit zijn slavenlading koos hij zich een negerin en een negerknaap voor fc 2.400 , kocht „chemises, jupes et culottes pour les habiller": voortaan zouden ze respectievelijk als kamermeid en boy fungeren. Uitgedost als mondaine gentleman had hij zich een horlogeketting en een wandelstok met zilveren knop en op een veiling een degen met ditto hecht en zeven versierde hemden aangeschaft. Tijdens zijn verblijf liet hij zich verder 4 vesten en 2 ondervesten in "toile royale", enkele goedkopere katoenen jasjes en 3 broeken, waarvan een fluwelen, vervaardigen. Tenslotte vulde hij zijn ,garde-robe" aan met een paar schoenen en 2 nieuw-overtrokken hoeden. Deze complete uitzet kwam hem op fc 687. Verwoed liefhebber van snuiftabak, verbruikte hij 5 flessen van dit goedje. Regelmatig bezocht hij de pruikenmaker. Op vrije avonden trok hij naar de tweede-rangs schouwburg; als trouwe klant miste hij geen enkele voorstelling en bezat hij zelfs een ,billet d'abonnement de commedie”. De rekening die hij aan zijn opdrachtgevers voorlegde beliep echter

(78) F.H. 967 - Journal du Mars. 
fc 4.207; tijdens zijn tien maanden verblijf had hij dus meer dan het dubbele van de hem veroorloofde som uitgegeven ${ }^{79}$. Zijn overtocht aan boord van de Prince de Montbazon betaalde hij fc 510. Hiervoor mocht hij dan aanzitten aan de kapiteinstafel.

Onder dezelfde voorwaarden aangeworven voor de Pompée-campagne drukten Portier-Frères hem ditmaal op het hart „... a regler la depence de façon que les interesses ne trouvent point a rdire et qu'elle ne devienne point a charge de votre armement". Onze kapitein deed het inderdaad nu wel wat zuiniger, maar besteedde niettemin op 14 maand en 20 dagen "pour frais de pension, blanchissage..." - nog fc 4.778/5/6 hetzij maandelijks ongeveer fc 325 verblijfsonkosten ${ }^{80}$.

In zijn reiskoffer op de Pactole stak een exemplaar der fabels van Esopos. Bewijs van literaire smaak of snobisme? Zijn pronkzucht kwam hem in elk geval duur te staan wanneer kort daarop in het Hollandse fort Shama op de Goudkust zijn diamanten ring ter waarde van ft. 500 in zijn slaapkamer gestolen werd. Ondanks een ernstig onderzoek, waarvoor van Alstein zelfs op de Gouverneur van El Mina beroep deed, bleef het kostbaar juweel spoorloos.

b) Een reislustige Nantese rentenier.

$\mathrm{Na}$ anderhalf jaar verblijf op Haïti bracht de lijnvaarder Pactole begin 1772 van Alstein terug thuis. Lang zou hij nochtans te Nantes niet vertoeven. Op 16 maart overhandigde hij de rederij het financieel rapport der Pompée-campagne en vertrok kort daarop, via Parijs, naar Vlaanderen. Onderweg bezocht hij zijn broer Louis-Gregoire, sinds 1765 pastoor te Bikschote bij Ieper en ging vermoedelijk terzelfdertijd te Comines-sur-la-Lys het graf van zijn moeder groeten. Ze was er in feb. 1769 overleden terwijl hij te Nantes de uitreding van de Pompée organiseerde. Reeds in juni reisde hij voor genealogische opsporingen door naar Gent en verbleef er nog steeds op 2 juli; ,je ne suis pas encore party de Gand et n'en connois de jour fixe" schreef hij naar Bikschote. Lang talmde hij niet meer; het reizen zat de zeerob echt in het bloed: „cependant lenvie de cheminer commence a me prendre, par consequent ne peux tarder...".

Aangekomen te Parijs, logeerde hij onbekende tijd ,a l'hotel de la Paix, rue de Richelieu au $\mathrm{p}^{\mathrm{r}}$ etage". Het volledig pension kostte er een buitensporige ft 270 . Terug in de Loirestad contracteerde hij in mei 1773 een nieuwe driehoekstocht, rustte te Nantes de Duc de Laval uit en bracht de cargo vervolgens naar $\mathrm{La}$ Rochelle waar hij zee koos ${ }^{81}$.

Ontscheept te Rochefort, reisde van Alstein begin juli 1775 door naar La Rochelle, sloot snel de rekeningen af en vertrok samen met zijn zwarte boy per diligence naar Nantes. Afgezien van regelmatige kleine uitstappen

(79) F.H. 982, $\mathrm{n}^{\circ} 12$ (Ordres et Instructions); F.H. 965, f 120 (Compte particulier); F.H. 973 (Onkostenrekening).

(80) F.H. $982 ; \mathrm{n}^{\circ 0} 17$ (Ordres et Instructions), $19,21 \ldots$

(81) F.H. 982, n 19 (rek. cour. Pompée); F.H. 361 - (Brief); F.H. $969-$ Livre de Connaissemens (nota's op binnenomslag). 
naar het platteland, zou hij hier bijna drie jaar onafgebroken resideren ${ }^{82}$.

Op uitnodiging van de weduwe Grou bracht hij in de nazomer reeds een paar weken door op haar aangenaam buitengoed La Placellière. Anne O'Shiell vertoefde graag op het ruime en luxueuse domein, gelegen ten Z.W. van Nantes tussen Vertou en Chateauthébaud, waar ze samen met haar verwanten Walsh en O'Shiell de stad ontvluchtte. Onze kapitein was op het kasteel wel een welkome gast, wiens exotische avonturen men met spanning in het salon beluisterde.

Te Nantes huurde hij bij de „Madelles Echappé" een bescheiden appartementje aan ft 24 per maand, doch liet zijn correspondentie steeds toekomen „ches $\mathrm{M}^{\mathrm{rs}}$ Montaudoüin frères" wat immers meer "cachet" gaf. Op straat pronkte hij in een pak uit fijn laken met satijnen voering en kanten manchetten, zijden kousen en ditto hoed, schoenen met zilveren gespen, gemslederen handschoenen en op zak een ivoren snuifdoos belegd met schildpad. De „négrillon au dépens de l'armement” van de Duc de Laval verworven, plaatste hij 8 maand op stiel bij zijn pruikenmaker Pommereau aan een pond per dag voor leergeld en pension. Eens volleerd, spande hij zijn persoonlijke kapper in met „rasoirs, peignes, cuirs, ciseaux, pommade liquide, poudre blanche". Daarna liet hij zijn boy overdag 9 maand lang school lopen. Voor het godsdienstonderricht bezorgde hij hem een „Imitation de Jesus, un livre d'Evangile". De kroon op dit bekeringswerk was dan de doop in ma. 1777 onder de naam van Jean Joseph Aza. De meester verzorgde zijn lakei uitstekend: aangetast door pokken, hospitaliseerde hij hem 12 dagen in het gasthuis; een kaakgezwel liet hij door zijn eigen chirurgijn opensnijden. Regelmatig kreeg hij zakgeld. Uitgedost met oorringen en een kleine zwarte hoed met zilveren boordsel, was hij wel een opvallende verschijning.

In de Loirestad sleet van Alstein het aangename, verfijnde en mondaine leventje der hoge burgerij. 's Zomers ondernam hij regelmatig ritjes op een gehuurd paard; 's winters hanteerde hij druk het floret in de schermzaal. Het ganse jaar door bleef hij een trouwe theaterklant: toneelvoorstellingen, Spaanse en Baskische dansers, concerten en zangrecitals, alles lokte hem aan. Daarbij ontpopte hij zich als een verwoed, evenwel weinig succesvol kansspeler, een liefhebberij die hem heel wat geld kostte. Jaarlijks boekte hij ,pertes au jeu”, zelfs ft 3.952/18 op 12 jaar tijd. Bijna maandelijkse „billets de la lotterie Royale", naast andere loterijen, bezorgden hem weinig geluk. Bij slecht weer liet hij zich in draagstoel naar de kerk brengen. Liefdadigheid was voor hem geen ijdel woord; daarvan getuigen zijn vrijgevigheid bij omhalingen, aan bedelaars en ft 300 ,,perte pour avoir preste au grand besoin d'un malheureux qui m'a trompé". Bezoeken aan La Placellière te paard of per koets waren legio. Ook met de familie Eustace te Ancenis op de Loire onderhield van Alstein goede relaties. Graag aanvaardde

(82) De grondige kennis van zijn verder curriculum vitae en ingewikkeld itinerarium danken we aan het memento waarin van Alstein de geringste uitgaven scrupuleus bijhield (F.H. 983 - Livre de Dépenses journalières). Aanvullende gegevens boden de correspondentie (F.H. 361), alsmede losse nota's uit rekeningen met de begeleidende brieven (F.H. 982, $\mathrm{n}^{\mathrm{os}}$ 19,65) en uit het connossementenboekje (F.H. 969). 
hij in jan. 1776 het peterschap over het derde kind van Françoise-Hélène Eustache, Dame Dachon ${ }^{83}$, en overlaadde de moeder met geschenken.

Dit overwegend residerend leventje werd hij blijkbaar beu; de reiszucht kreeg de zeebonk opnieuw te pakken. Per postkoets bolde hij in mei 1778 via Lorient naar Brest en keerde over Rennes terug. Kort daarop vertrok hij met de diligence naar Parijs. Zijn boy vergezelde hem in de bagagewagen. Aangekomen op 1 juli logeerde hij 3 maanden in bescheiden pensions van het St. Honoré-kwartier. De maandhuur in Hôtel de Lusignants (rue des Vieilles Etuves) en Hôtel St. Maurice (rue des Boucheries) kwam nauwelijks op ft 40. Zijn mondaine levenswandel gaf hij er echter allerminst prijs: hij zat aan de "table d'hote" aan, bezocht "caffés, guingettes, spectacle divers", reisde met vrienden naar Chantilly, benutte "chaisses aux promenade et a l'Eglise" en speelde partijtjes ,jeu de Wisque, piquet, lotto". Vooral zaken weerhielden hem in de hoofdstad, o.m. belangen in de pas opgerichte waterleidingsmaatschappij.

Jean Joseph Aza deserteerde kort na de aankomst. Ronddolend gesnapt en opgesloten in de gevangenis kreeg de eigenaar hem terug mits vereffening der zware onkosten. Grootmoedig "luy ai pardonné sa fautte", ondanks de ft 254 die dit avontuur aan zijn meester kostte, plus verzorging en doktersuitgaven tijdens zijn twee weken herstel. Terug te Nantes zou hij een heropvoeding krijgen in de ,ecole du pègre", de boefjesschool.

De thuisreis ging over land tot Orléans en verder per bark de Loire stroomafwaarts tot Mauves, waar ze landinwaarts afsloegen naar La Placellière. Opnieuw gehuisvest bij de gezusters Echappé hernam hij zijn vroeger kalm burgerleventje, met als afwisseling ,... passer quelques tems a la campagne... chèz Made Grout a la Placelière pres Nantes". Zijn robuste gezondheid spaarde hem van zware kwalen. Alleen in aug. 1780 lag hij 20 dagen ziek te bed; na ,2 saignées et 4 visites" vanwege de chirurgijn was hij echter weer te been.

Begin 1781 verkocht de Viconte de Segonsac zijn vriend voor ft 360 een sjees, waarmee deze een nieuw en zwaar reisprogramma zou afwerken. In de meimaand trok van Alstein, in gezelschap van zijn zieke lakei, met zijn eigen voertuig via Le Mans en Versailles naar de hoofdstad. Aan elke wisselplaats huurde men voor $\mathrm{ft}$ 4/15 een ander postpaard. Een paar dagen onderkomen in een Parijse $2^{\text {de }}$-klasse herberg volstonden om de negerknecht in behandeling te plaatsen bij een "... medecin... jusqu'a parfait traitement... pour le faire guerir des piants..." 84 .

Per postkoets ging het nu naar Brussel; na een kort oponthoud aldaar, via Doornik en Kortrijk, verder door naar Gent. Weer was een speurtocht naar afstammingspapieren de drijfveer voor dit blitzbezoek aan de Oostenrijkse Nederlanden. Binnen de maand juni was hij, via Rijsel, terug te Parijs, waar hem een ontgoocheling wachtte: pas genezen, trok zijn on-

(83) De dochter van Hélène-Claire Gough huwde met François-Amand-Jean-Baptiste Dachon, ,seigneur de Bellière..., ancien capitaine d'Infanterie et chevallier de l'ordre Royal et militaire de Saint-Louis (F.H. 959).

(84) Pian was een besmettelijke ziekte gekenmerkt door huiduitslag, die ontaardde in weerzinwekkende zweren en tenslotte het beendergestel aantastte. Vooral Congo. negers waren vatbaar voor deze kwaal. 
dankbare boy er opnieuw van onder en ditmaal voorgoed.

De volgende maand bracht zijn eigen sjees hem opnieuw naar Gent. Het verblijf duurde er ditmaal een drietal maanden. Vermoedelijk gelogeerd bij zijn zuster Anne-Thérèse vaarde hij met de trekschuit naar Oostende en bezocht Antwerpen. Zijn bezoeken aan de families de Loose en Jacobsens laten zakenrelaties vermoeden. Op de terugweg naar Parijs liep hij nog even aan bij zijn broer Louis-Grégoire, pas pastoor benoemd te Reninghelst bij Ieper.

Op 21 okt. opnieuw in de Franse hoofdstad, installeerde hij zich tot 4 feb. 1782 in een kamer van het „Hôtel d'Artois, rue Traversière au $2^{\text {nd }}$ etage" aan ft 60/maand. Het frivole uitgangsleven — ,comédie aux variétés, italienne, françoise" - viel blijkbaar mee. Kennissen waren er genoeg en bij de verwante Goughs was hij steeds welkom. In de luxe-magazijnen vulde hij zijn uitzet aan met „un habit de drap, une vest d'etoffe, un chapeau demi-castor, un ceinturon de soie verte, 14 boutons argent damasquinés en or, une tabatière d'ecaille, une épee d'acier a diamant".

Binnen de 10 dagen stond hij, via Le Mans en Angers, op $15 \mathrm{feb}$. weer te Nantes; onderweg vereerde hij zelfs Ancenis met een bezoek. Een daaropvolgende tocht ging naar Bordeaux, waarschijnlijk op uitnodiging der rederij Nairac met het oog om een eventuele nieuwe campagne. $\mathrm{Na}$ een paar afscheidsbezoeken, o.a. aan $\mathrm{M}^{\mathrm{e}}$ Grou op La Placellière en aan Ancenis, keerde hij in volle winter van 1783 terug naar de havenstad uit het Girondegewest om er het bevel over de negercargo Pactole te aanvaarden. Voor deze rit op winterwegen met eigen wagen ondernomen, schafte hij zich een "planc routier" en een "planc de Bordeaux" aan. De afvaart naar de Coste d'Or greep plaats op 28 april.

Bij de ontscheping op 28 nov. 1784 begroette kozijn F.A. Dachon de schoonzoon der Eustaces - van Alstein op de Garonnekaaien. Nu zwaaide de slavenkapitein de zee een definitief vaarwel toe; zijn $51^{\text {ste }}$ verjaardag had hij zopas nog aan boord gevierd. Samen reden ze in de sjees terug naar Nantes.

Juist vóór Kerstmis thuis, nam hij dadelijk zijn intrek in een ander appartement bij een zekere $M^{\text {me }}$ Grisale aan $f t 40 /$ maand. Half maart 1785 huurde hij een nog goedkoper onderkomen bij zijn kleermaker Hubert aan ft 25 . Kort daarop verhuisde hij voor de rest van het jaar bij $\mathbf{M}^{\mathrm{me}}$ Gadebois aan hetzelfde zuinig tarief. Toen hij in sept. van La Placellière terugkeerde met een zenuwontsteking in het been, paste zijn nieuwe hospita hem zorgvuldig op.

In jan. 1786 installeerde de rentenier zich definitief in het „Hotel de Madame Grou, Isle Faye d'Oyes (Feydeau)". Rond deze tijd trok Anne O'Shiell zich uit de zaken terug en nam haar intrek in dit ruim en weelderig herenhuis op het Loire-eilandje, eigendom der familie Grou. Kinderen en kleinkinderen harer beide zusters kwamen op haar verzoek inwonen. De tweede verdieping echter werd verhuurd. Daar verwierf P.I.L. tenslotte als onderhuurder ,... une chambre chez $\mathrm{Mons}^{\mathrm{r}}$ et Made Richarme pour $300 \mathrm{lb}$ par an, payable $150 \mathrm{lb}$ de six mois en six mois".

Een nieuwe drukke reisperiode stond nu voor de deur. Zijn sjees bracht hem achtereenvolgens via Orléans naar Parijs - waar hij de ganse juni- 
maand in het Hôtel d'Espagne resideerde aan ft. 60 - verder naar Reninghelst, terug naar Rijsel en tenslotte naar Gent. Tijdens zijn verblijf van twee maand verzamelde hij er voor de zoveelste maal genealogische papieren; ook Brussel werd met dit doel aangedaan. Een jachtpartij in de ZeeuwsVlaamse wateringen bracht wat afwisseling. Op de terugweg naar Nantes vertoefde hij nog een maand in Hôtel de Nismes te Parijs.

De winter van 1786-87 bleef hij knusjes thuis op zijn kamer. In mei bolde hij echter opnieuw naar de hoofdstad om er $31 / 2$ maand lang te verblijven in het „Hôtel de l'Empereur, rue Grenelle - St. Honoré”. Naast zakenafhandelingen - notariële eigendomstitel voor de schorren van Noirmoutier - was het hoofddoel van deze tocht het verwerven der Franse nationaliteit.

In volle revolutionnaire oproer reisde hij in de nazomer van 1789 een laatste maal naar Vlaanderen. Te Gent nam hij afscheid van zijn zuster, die twee maand later zou bezwijken. Wegens de ongunstige tijden vroeg de ex-Gentenaar voor de terugreis voorzichtigheidshalve aan zijn geboortestad een vrijgeleide ,... versoeckende aen ider van hem gerustelyk te laeten gaen ende komen met zijn effecten...". Dit paspoort bevat daarenboven de enige summiere persoonsbeschrijving die we van de reeds vergrijsde slavenkapitein bezitten: „Jor Pieter-Ignatius-Livinus van Alstein, wit hayr, roste wynkbrouwen, bruyne oogen, dicken neuze, wel op syne beenen, oud 52 jaeren, lang vijf voeten, vier duymen..." (ongeveer $1,73 \mathrm{~m}$ ). Waarschijnlijk voelde van Alstein zich in het revolutionnaire Frankrijk veiliger met de vrijgeleide der Vlaamse stad die hem "onsen insetenen" noemde, dan met zijn naturalisatieaktie ondertekend door de gehate Lodewijk XVI. Volgens zijn reisplan wenste hij immers „... partir pour Paris en allant par Ipres ou il compte de sejourner quelques tems...", wat natuurlijk op Reninghelst doelde. Hij verbleef er bijna anderhalve maand bij broeder-pastoor, vermits de Rijselse regeringscommissaris pas op 14 nov. 1789 een „Bon pour aller a Paris" aanbracht. Hiermee kwam een einde aan alle persoonlijk contact met de familie; ze zouden hem nooit meer weerzien.

Terug in Nantes benutte hij als pseudo-Vlaming deze vrijgeleide nog tweemaal in 1791: in mei voor "Chalans \& autres lieux de Poitou", in juni om naar Chollet te reizen ${ }^{85}$. Vanuit Challans ging hij waarschijnlijk de ontginningswerken van Noirmoutier inspecteren en beval de onmiddellijke stopzetting.

Tijdens de periodes van inactiviteit te Nantes, dacht van Alstein er nooit aan zijn haardstede definitief in te richten, laat staan een gezin te stichten. Alhoewel D. Garesché hem in $1776, \ldots$ une bonne santé et une bonne femme..." wenste, hechtte hij blijkbaar meer belang aan zijn blakende constitutie. De ex-kapitein legde het zeer economisch aan boord: de zwaarste onkostenpost veroorzaakte zijn pronkkledij om op de recepties der hoge burgerij uit te blinken. Voor het behoud van zijn boy als lakei en zwart curiosum getrooste hij zich hoge uitgaven.

Zowel te Nantes als onderweg koos hij steeds goedkoop onderkomen uit.

(85) F.H. 64, $\mathrm{n}^{\circ} 224$ - Vrijgeleide (30 sept. 1789) afgeleverd door de „Schepenen vander Keure ende Raed der Stadt Gend". 
De ft 270 in 1772 in een Parijs Hotel neergeteld, bestempelde hij later als "folies". Nooit bestelde hij meubels of bezwaarden copieuze maaltijden zijn budget. Gewoon an de enge scheepshut, bleef hij steeds tevreden met een bescheiden appartementje. $\mathrm{Na}$ het verlies van zijn negerknecht, beperkte zijn gezelschap er zich tot een sprekende Senegalese papegaai. Deze aan vrekkigheid grenzende spaarzaamheid verergerde nog sinds hij in het Hôtel Grou woonde: „... il n'avoit point de mobilier, il logeoit en petite chambre garnie, n'avoit point de domestique, prennois son repas de l'un bout de l'année a l'autre chez Madme Ve Grou. Il m'est tres connu quil ne depensoit pas ft 1.500 par an" ${ }^{86}$. Tussen 1748 - „depuis que j'ai quitté mon pais la Flandre et mon arrivée a Nantes" - en de afmonstering te La Rochelle in juni 1775 totaliseerde hij ft 18.686/6/3 aan uitgaven, hetzij een minimale ft. 692 /jaar. Zijn huisjournaal, dat de periode juli 1775sept. 1787 bestreek, sloot met ft. 52.166/6 aan dagelijkse onkosten. Onder het jaargemiddelde van ft 4.347 vallen echter ook reisonkosten, zeeverzekeringen, droogleggingsuitgaven, enz. Zelfs dit alles nog meegerekend, leefde van Alstein voor minder dan ft 12 per dag! De hogervermelde ft 1500 jaaruitgaven kloppen bijna voor de termijn okt. 1787 - mei 1791 : een jaarlijks budget van nauwelijks ft. $1.699 / 9$ wat een povere ft. 4/13 per dag betekende of de prijs van een pond goede tabak ${ }^{87 !}$

E.

DE CONSOLIDATIE DER VERWORVEN STANDING.

Dank zij een fortuinlijke loopbaan en een flinke financiële ruggesteun had van Alstein toegang verworven tot het gesloten milieu der hoge burgerij. In zijn poging om verder door te dringen in de rangen van de aristocratie deelde hij het tijdsideaal zijner geestesgenoten. De kring van relaties die hij zich opbouwde stond dan ook volledig in het licht van dit streven. In zijn adressenlijst figureerden klinkende namen van Franse edelen die in het Parijse Quartier St. Germain resideerden (de Luker, Stapleton, du Laurent, de Nermont, Boutellier). Onder zijn Nantese kennissen telde hij de aanzienlijke reders Montaudoüin, Villeboisnet, Boucard en Pelloutier. Zijn correspondentie overspande Parijs, Bordeaux, Cadix, Wenen, Keulen, Ieper en Gent (o.m. zijn verre verwant Edward-Grégoire van Alstein, „hooye pointre d'Oudenaerde”).

(86) F.H. 361 - J.B. Van Damme aan J. van Alstein (Nantes, 17 Thermidor, An 3 - 3 aug. 1794).

(87) F.H. 983 - Livre de Dépenses journalières ; F.H. suppl. 56, f॰ 12. 


\section{1) Adelbrieven en naturalisatie.}

Eens zijn succesvolle sociale opgang zich begon af te tekenen, spande de uitgeweken Gentenaar zich in om een voorgewende aristocratische afkomst te funderen. Hij zette derhalve een reeks speurtochten naar familie- en afstammingspapieren in, teneinde de adellijke oorsprong zijner voorouders te bewijzen, zo nodig te forceren. Deze campagne startte reeds in $\mathbf{1 7 7 2}$. Tijdens de reis naar Vlaanderen nam hij de gelegenheid te baat om vooreerst zijn rechtstreekse afstamming te reconstrueren. Het gelukte hem al de Gentse voorouders terug te vinden: „... jusqu'a present $j$ 'ai assez bien trouvé tout ce que je cherchois; j'ai presentement un arbre genealogique depuis notre triayeul jusqua notre individue du cote de notre pere et tous les enfants nés de differentes alliances; deplus un autre du cotte de notre grande mere Jeanne Catharine Lievens...". Gezegelde en gelegaliseerde afschriften uit de parochieregisters bewezen de authenticiteit van zijn stamboom. Tot hiertoe blijkbaar op het goede spoor, achtte hij het zelfs nodig „que je voye a Cologne si je trouverai le $1^{\text {e }}$ Piter V A Precident et l'extrait baptistaire de son fils Pierre premier etably a Gand".

De juiste versie paste nochtans niet in zijn kraam, want in deze tak was er geen blauw bloed voorhanden. Er bleken echter aristocratische dubbelgangers en de schrijfwijze van de familienaam bood variaties genoeg (Haelsteyn, (van) Halstyn, van Alstyn, van Alstein) om de zijsprong te wagen: "vous voyez la comme les noms sont differement ecrits, faute des contractans, et quel moyen de chicane malgré que les alliances prouvent beaucoup..."' 88 .

De Vlaamse kapitein droomde van meer illustere voorouders. Eigenhandig stelde hij memorialen op waarin hij pretendeerde af te stammen van Oostenrijkse hofadel, met als enige verwantschap een gelijkluidendheid in de familienamen ${ }^{89}$. Naar hij voorhield was de stamvader van het Gentse geslacht Maximilien de Waldstein, geboren in 1564, Opperstalmeester en -kamerheer van de Keizer, in 1589 gehuwd met Catherine, Gravin van Harrach, zuster van Kardinaal Ernest-Adelbert. Tijdens de Duitse godsdienstoorlogen zou de zoon Pierre in het veilige Gent ondergebracht worden bij de groot-baljuw della Faille. Men verbasterde er de naam tot Valstein, Halsteyn, tenslotte vervlaamst in Van Alstein. Zonder enige bewezen titel huwde Pierre in 1619 Catherine D'hamere. De intussen hertrouwde vader liet niet meer van zich horen. P.I.L. van Alstein nam het eerherstel van deze gelijknamige voorouder op zich, miskend „... fautte de pieces authentiques de reclamer ses droit naturels". Daarmee diende hij natuurlijk zijn eigen zaak: zo deze bedriegelijke poging lukte was de adellijke afstamming bewezen.

De ernstige bevlieging kwam in 1781. Uit Nantes vertrokken eerst en-

(88) F.H. 361 - P.I.L. van Alstein aan Louis-Gregoire (Gent, 2 juli 1772).

(89) ibidem - Extrait des divers manuscrits de la famille Waldstein, Walstein, Valstien, en Espagne Balstein, en France communem Vallenstein, en Flandre Halsteyn et finalement van Alstein. (Opgesteld rond 1780-81, vermits het achteraan vermelde huwelijk van Ed.-Gr. van Alstein met Charlotte de Loose in mei 1779 plaatsgreep). 
kele brieven naar Wenen en Duitsland om aanvullende inlichtingen over de vermeende afstamming. Vervolgens toerde hij meer dan 3 maanden in de Oostenrijkse Nederlanden rond om er de laatste bewijsstukken te verzamelen. Terug te Parijs, zond men uit Gent nog ,un boite de fer blanc... contenant papier de famille" achterna. Terzelfdertijd liet hij door een Parijse notaris de "état des papiers de la famille Gough" opmaken ${ }^{90}$. De Pactoleexpeditie stelde echter de bekroning van deze inspanningen uit.

Eindelijk viel in 1786 de beslissing. Op basis van zijn eigenhandig samengesteld memoriaal leverde de Madrileense genealoog Ramon Zazo y Ortega na een lang betoog over oorsprong, heldendaden en familiewapen van het geslacht van Alstein, een „certificat d'armes... pour que le dit don Pierro-Ignace-Livino Van-Alstein, ses enfans et autres légitimes descendans puissent se servir... des dites armes". Het honorarium van de heraldiekspecialist kwam op ft 9.903; de officiële Spaanse bekrachtiging en de Franse vertaling beliepen ft 498. Op 16 nov. 1786 werd de Franse versie

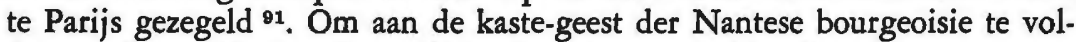
doen gaf van Alstein zijn traditionele spaarzaamheid prijs.

Tijdens zijn verblijf te Gent schafte de koopman zich nogmaals drie gelegaliseerde afschriften uit de parochieregisters van St.-Michiels aan, vereist om te Brussel een adellijk diploma los te krijgen. Op 27 okt. 1786 kwam dan de officiële erkenning én van zijn adeldom én van het wapenschild waarvoor hij graag fl. 53/11/6 overhad. Voortaan mocht van Alstein zijn eigen familiewapen voeren: een gouden schild, gedwarst door een sinopel-groene band met drie zilveren kruisen; daarboven een zilveren helm met zilver-groene uitwaaiers, bekroond met een zilverkruis tussen twee vleugels ${ }^{22}$.

$\mathrm{Na}$ zijn talrijke speurtochten naar familiepapieren beoogde hij eveneens de uiteindelijke naturalisatie tot Frans staatsburger. $\mathrm{Bij}$ de aankoop der schorren van Noirmoutier wilde hij zijn rechten als grondeigenaar waarborgen. Reeds 40 jaar in Frankrijk gevestigd en toekomstig domeinheer, had hij er volstrekt geen belang bij nog langer als vreemdeling geboekt te blijven. Lodewijk XVI willigde de aanvraag in en ondertekende te Versailles in aug. 1787 de naturalisatiebrieven. Voortaan was P.I.L. van Alstein "notre vrai et naturel sujet regnicole" met al de bijkomende burgerrechten.

(90) F.H. 983 - Livre de Depenses; passim. Zijn adresrepertorium vermeldde de indrukwekkende namen Kaunitz (Conseiller d'Etat intime) en Cobentzel (ViceChancelier et Ministre d'Etat).

F.H. 959 - Titres de Noblesse d'extraction de la $D^{\mathbf{e}}$ Mere de S. van Alstein (1781).

(91) F.H. 361 ; documentatiemateriaal : F.H. 361 ; Genealogie du Comte de Waldstein; Origine de cette maison; Les terres, armes et titres des comtes de Waldstein - F.H. 959 ; Heraldisch certificaat (24 pp.) - F.H. 64, f 114 en F.H. 986 ; Onkostenrekeningen.

(92) F.H. d'Hoop, op. cit., p. 261 ; bijlage : Copie authentique d'un diplome avec les armoiries coloriées - F.H. 369 ; ontvangstbewijs vanwege de koninklijke wapenheraut C. Beydaels De Zittaert, die de adelbrieven mede had ondertekend - Reeds op 17 jan. 1771 had keizerin Maria-Theresia te Wenen "lettres patentes de noblesse" verleend aan Pierre-Grégoire van Alstein, kleinzoon van P.I.L.'s overgrootvader $(O p$. cit., p. 260). Het hogergenoemd genealogisch receuil bevat een afbeelding van het familiewapen (p. 186). 
De onkosten bleken vrij hoog: de advokaat Meribeke ontving als ereloon voor zijn administratieve bemoeiingen ft 285 ; het „,bureau des insinuation" (registratiekantoor) vroeg $\mathrm{ft} 150$, tenslotte nog de registratie in de Parijse Rekenkamer aan ft 353 , alles samen een ft $800^{\circ 3}$.

\section{2) De aankoop van een domein ${ }^{24}$.}

Vrij vroeg scheen van Alstein al plannen te koesteren om zijn fortuin in grondbezit om te zetten. Reeds in 1773 - een koloniale malaise en de latente internationale spanning, voorbode van de Zeeoorlog, begonnen zich toen af te tekenen - hield de slavenkapitein bij de contractering voor de Duc de Laval rekening met „... le cas ou quelqu'achat d'habitation ou autre raison me feroit quitter la mer et me mettroit dans le cas de rassembler mes fonds". Daar kwam toendertijd niets van in huis. Zelfs de schorrenontginning te Noirmoutier vanaf 1787 was eerder als speculatie dan als belegging te beschouwen.

Eerst in 1791 realiseerde hij zijn oude plannen. De economische ineenstorting en de gelddevaluatie veroorzaakt door de Revolutie, waren zeker niet vreemd aan deze beslissende stap. Vermoedelijk ingelicht over de verkoop door zijn vriend Marquis de Laurens - echtgenoot van Marie de Stapleton, residerend te Gennes - werd hij in de zomer van 1791 eigenaar van het herengoed op het gehucht „La Roche de Gennes”, paroisse de St. Eusèbe sur Loire en Anjou entre Angers et Saumur". Gelegen nabij Gennes in het huidige departement Maine-et-Loire, omvatte het verspreide domein de hereboerderij met aanpalende tuin, wijngaard en bosje; een kleine pachthoeve met bijhorende schuur, stallen en gronden; twee uitgestrekte partijen pachtgrond; twee watermolens, de ene in werking, terzelfdertijd boerderij met tuin, paardestal en overige nevengebouwen, de andere in onbruik bij gebrek aan onderhoud; $2 / 9$ in de grote watermolen van Gennes; tenslotte akkerland, weiden, teenwilgaanplantingen, kreupelhout- en kastanjebossen. Als heerlijke privilegies kwamen hem verder nog toe het aanstellingsrecht in de kapel der priorij le Thoureil en een bank in het koorgestoelte van de parochiekerk St. Eusèbe.

De totaaloppervlakte bedroeg „62801/2 perches, faisant $7533 / 5$ boissettées, mesure de Saumur", hetzij ongeveer 41,42 ha ${ }^{25}$. Voor dit aanzienlijk domein telde van Alstein ft 60.500 neer. Met registratierechten, aflegging van bezwarende renten, dringende herstellingswerken en bouwmaterialen, nieuw materieel en meubilering liep dit op tot $1 \mathrm{t} 75.300$.

Gelijktijdig kwam hij in het bezit van de hoeve La Bardinière met de bijhorende gronden, eveneens in de St. Eusèbe-parochie op een mijl af-

(93) F.H. 965, $\mathrm{n}^{\circ} 122$ - Lettres de Naturalité pour le sieur Van Alstein.

(94) F.H. suppl. 56, fox 20 à 23 - Achat de la terre de La Roche de Gennes...; Acquisition de la terre des Bardinières; $f^{\circ} 12$ - Dépenses; $f^{\circ} 8$ - Produit de ma terre de la Roche de Gennes.

(95) F.H. 1009 - Copie du plan des Domaines dependant de la Maison de laroche (mars 1791) — „La mesure de Saumur pour la boiss ${ }^{\circ}$ est 8/13 chaines; la chaine de 25 pieds $(8,12 \mathrm{~m}) . "$ De roede (perche... de 25 pieds de longeur), als oppervlaktemaat in het kwadraat, bedroeg dus $65,95 \mathrm{~m}^{2}$. 
stand van het eerste herengoed gelegen. Aankoopprijs en bijkomende onkosten bedroegen hier ft 10.443 .

Einde 1793, nog volop bezig met de inrichting van beide domeinen, stak van Alstein volgens zijn abrupt afgebroken boekhouding er reeds ft 86.828/18 in. Ondertussen had La Roche zijn eerste vruchten gedragen: de opbrengsten aan pachtgelden, natura-cijnsen en verkoop der landbouwprodukten bedroegen respectievelijk ft $2.978 / 12$ in 1791 en reeds $\mathrm{ft}$ $1.303 / 5$ „pour l'année courante" 1792.

\section{3) Geldplaatsingen in de vreemde.}

Bevreesd voor de onzekere toekomst, legde van Alstein een buitenlandse geldreserve aan. Hiervoor deed hij beroep op Vlaamse relaties, en deponeerde Franse deviezen bij zijn vriend, de Gentse negotiant-bankier JeanBaptiste de Loose ${ }^{96}$.

In aug. 1791 zond hij per schip een partij gouden louis ter waarde van ft 7.992 naar Oostende. Verduisterd door de scheepskommandant, liet de Loose deze arresteren en kreeg de zending te Brugge terug. De bankier vroeg van Alsteins instemming om het geld in Russische, Zweedse of Deense staatsleningen "qui donnent $5 \%$ et sur coupons" te investeren. In afwachting werden fl. 4.000 ct gedurende drie maand à $4 \%$ in Holland uitgezet.

Een paar maanden later ontviel van Alstein ook dit toevluchtsoord: „,je ne peux nullement vous conseiller... a faire passer ici vos argents, soit en nature, soit en marchandises; les affaires ne vont pas...". Bij de Gentse zakenman waren op dat ogenblik ongeveer ft 10.000 gedeponeerd. Gewaarschuwd door dit pessimistisch bericht, begroef P.I.L. 21 zakken muntstukken op een nooit teruggevonden plaats ${ }^{97}$.

E.

\section{DE INEENSTORTING VAN EEN LEVENSWERK.}

\section{1) Slacbtoffer van de Terreur.}

Nantes begroette met enthoesiasme de uitroeping van de Republiek op 21 sept. 1792. De bloedige Vendée-oorlog, het royalistische antwoord op de terechtstelling van Lodewijk XVI, ontnuchterde echter de Loirestad die een belegerde vesting werd. Buitenlandse militaire nederlagen, interne onlusten en de paniekstemming in het land noopten de Nationale Conventie uitzonderingslichamen in het leven te roepen: het "Comité de Sûreté Générale" zou de binnenlandse vijanden van het regime verdelgen. De daaropvolgende "Loi sur les Suspects" ontaarde vlug in de meest willekeurige

(96) Zijn dochter Caroline huwde in 1779 Edward-Grégoire van Alstein, hoogpointer der kasselrij Oudenaarde, woonachtig in de Posteernestraat te Gent.

(97) F.H. $364 ; 367$ - Correspondentie J.B. de Loose - van Alstein (Gent, 21, 28 aug., 22 sept. 1791 ; 20 jan. 1792). 
arrestaties en terechtstellingen; ook te Nantes draaide de Terreur op volle toeren.

Pas was Anne O'Shiell op 28 juli 1793 overleden of de inwonende verwanten en kennissen van het burgerlijke Hôtel Grou kwamen op de lijst der verdachten terecht. Hun aanhouding volgde kort daarop. Opgesloten in een interneringsgebouw - het voeger Clarissenklooster - overviel een epidemie de 60 -jarige grijsaard. Koortsig en zonder verzorging, werd hij stervend geëvacueerd naar het revolutionnaire hospitaal en bezweek tijdens deze overbrenging op $27 \mathrm{dec} .1793^{98}$. Hij stierf op de vooravond van de afschaffing der slavernij, de sociale instelling waaraan hij zijn fortuin grotendeels te danken had.

Alhoewel hij zijn einde niet vond in één der beruchte Nantese klepboten, viel de ex-kapitein toch als onschuldig slachtoffer van de Terreur. Toevallig, in dramatische omstandigheden, en zonder grondige redenen gearresteerd, vermelde de akte der inhechtenisneming eenvoudig: „Le concierge de la maison d'arret de St.-Claire retiendra sous bonne \& sure garde le nommé Pierre van Alstein, faisait partie du nombre des huit personnes". Bij de confiscatie van het Hôtel Grou, "la nation s'est emparée de son petit mobilier..." Op de veiling leverden de schamele bezittingen van de gevangene nauwelijks een povere ft 393/11/8 op. De opbrengst kwam terecht in de kas der Domeinen ${ }^{89}$.

\section{2) De Ontbinding van bet Fortuin.}

De reconstructie van het fortuin van de overleden van Alstein werd vergemakkelijkt door het onderzoek dat de erfgenamen instelden. In aug. 1792, juist vóór de Septembermoorden de uitroeiing der aanhangers en bevoordeelden van het Oud-Regiem inzetten, maakte de begoede rentenier zelf de balans op van zijn bezittingen. François-Amand Dachon vestigde zich na de opheffing der inbeslagname op het domein van $\mathrm{La}$ Roche. Vermoedelijk vond deze mede-erfgenaam de staat in de verzegelde woning terug, waar van Alstein hoogstwaarschijnlijk de zomer van 1792 doorgebracht had 100 .

Deze bondige en overzichtelijke inventaris geeft ons een volledig en juist beeld van zijn financiële positie op een ogenblik dat zowel grote uitgaven als aanzienlijke inkomsten achter de rug waren.

— Billets: ft 92.597/10.

De meeste schuldenaars die het uitgezette kapitaal - som waarin ook reeds de intresten begrepen waren - ontleenden, bleven dubieus, enkelen zelfs totaal insolvent: ,,vous avés a craindre que vous aurez des non-valeurs dans les billets, les debiteurs sont tous nobles et je presume que la majeure partie s'est emigrée...".

(98) D. Rinchon, op. cit., p. 32.

(99) F.H. 361 - J.B. Van Damme aan Joseph van Alstein (Nantes, 2 Ventôse, 17 Thermidor, 3 me Année de la République - 20 feb. 5 aug. 1795).

(100) F.H. 366 - J.B. Van Damme aan J. van Alstein (Nantes 9 jan. 1796) „,... $\mathrm{M}^{\mathrm{r}}$ Dachon $\mathrm{m}^{\prime} \mathrm{a}$ remis les pieces suivantes concernant la succession de P.I.L. van Alstein : $7^{\circ}$ Copie du Relevé... de son avoir, arrêté le 8 aout 1792". 
- Loose a G.: ft 10.002 .

Over de goudreserve, door van Alstein bij J.B. de Loose te Gent gedeponeerd, konden de Vlaamse erfgenamen ter plaatse beschikken.

- 21 S. a A.: ft 18.905.

De geldschat van 21 zakken die de vooruitziende en bevreesde rentenier ergens in de grond stopte om op elke eventualiteit voorbereid te zijn, bleef voorgoed verloren.

- Gennes: ft 200.

Misschien een kleine schuldvordering in het nabij gelegen Gennes, zonder enige verdere aanduiding.

- La Roche \& Bardinière: ft 86.828/18/3.

Zoals de boekhouding aangeeft, waren dit de uitgaven aan het domein besteed (aankoop, herstel, verbouwing, diverse onkosten). Het verder wedervaren van het herengoed komt nog ter sprake.

- Desechement de Noirmoutiers: Lt 8.741/12.

Naar de werken in de droogleggingsconcessie - aangekocht voor $\mathrm{ft}$ 4.500 , waarbij ft 108/16/9 notaris- en registratiekosten kwamen waren in 1792 reeds $\mathrm{ft} 4.132 / 5 / 3$ gegaan.

- Bordereau ci-joint: ft 7.474/1.

Hoogstwaarschijnlijk beschikte van Alstein in deze periode over een aanzienlijke som baar geld om de behoeften van zijn pas-aangekocht domein te dekken. Het was niet uitgesloten „... qu'il pouvoit avoir cette somme sur lui dans sa captivité, qu'il en aura depensé partie et que le reste aura été volé à sa mort".

- En portefeuille: ft 47.

Zakgeld voor dagelijkse onkosten.

Op zijn financieel hoogtepunt bezat van Alstein dus een globaal fortuin van ft 224.749/1/3. Volgens de inventaris, opgemaakt na de verbreking der zegels, bevonden er zich op La Roche nog ft 1.234 aan meubels en alaam. Deze roerende goederen zijn echter reeds begrepen in de hogervermelde totaalwaarde van het domein.

Hoger reeds berekenden we het kapitaal nà zijn vóórlaatste expeditie; vermeerderd met een erfenis en de eerste leningen, mag dit begin 1776 geschat worden op ongeveer ft 65.000 . Voor 1775 slechts ft $34 / 4$ getakseerd, diende hij bij de „capitation" van 1776 reeds ft 60/1 belastingen af te dragen. De heffing bleef dezelfde gedurende de twee volgende jaren. Voor 1781-82 samen belastte men hem voor ft 144. Volgens deze laatste fiscale maatstaf zou het fortuin inmiddels dus aangegroeid zijn tot rond ft 80.000 . Dat de reuzesprong plaats greep tussen $1783-93$ is niet denkbeeldig, aangezien van Alstein in dit laatste decennium aan intresten alleen reeds $£$ t 79.183 inkomsten boekte ${ }^{101}$.

(101) F.H. 983 - Livre des Dépenses (Capitations); F.H. suppl. $56 \mathrm{f}^{\circ} 12 \mathrm{v}^{\circ}$ : Recette d'interet recu... jusquau $\mathrm{p}^{\mathrm{r}}$ janvier 1793. 
3) De erfgenamen.

Zodra na de val van Robespierre het burgerlijk Directoire weer enige veiligheid bood, waagden de erfgenamen het aanspraak te maken op van Alsteins nalatenschap. Pastoor Louis-Grégoire, „... heritier universel de son frere unicq feu Pierre Ignace Lievin...", droeg zijn verre neef Joseph-Hector-Felix Van Alstein op de zaak te behartigen. Deze stelde zich in verbinding met Jean-Baptiste van Damme, geboren Gentenaar en Nantees negotiant: ,je me chargerai volontiers de la reclamation de la succession de feu notre ami Van Alstein; le travail sera penible" luidde het gunstig antwoord.

Ondertussen had François-Amand Dachon, eigenaar te Ancenis, gehuwd met Françoise-Hélène Eustace en „... en cette qualité héritier presomptif pour un quart du coté maternel de (Louis-Grégoire) Van Alstein, prêtre", zich als beheerder op La Roche gevestigd, daartoe gevolmachtigd door de nieuwe eigenaar. Dachon bezorgde van Damme alle documenten die de fortuinverdeling aanbelangden: „... le livre du defunt, qui contient le placement de ses fonds... en même tems divers papiers"; deze laatste zou zich tevens met de schuldvordering te Nantes gelasten ${ }^{102}$.

Het domein van $\mathrm{La}$ Roche-Bardinière liep inmiddels opnieuw gevaar onder sequester te komen. De eigenaar Louis-Gregoire was een onbeëdigd priester die bovendien zijn standplaats Reninghelst had verlaten: dit alles volstond om hem als „moine emigré". te brandmerken. Om in elk geval een gedeelte van het fortuin aan de revolutionnaire klauwen te onttrekken droeg hij voor ft 15.200 (fictieve verkoop?) het herengoed over aan JosephHector-Felix van Alstein en diens schoonbroer Antoine-François d'Hoop ${ }^{103}$.

Een man die bij zijn dood een fortuin van meer dan ft 224.000 in eigendommen, titels en baar geld achterliet, mocht zich gerust tot de „highsociety" van Nantes rekenen. Zijn verdiensten waren des te groter, vermits hij zijn vermogen omzeggens volledig op eigen kracht verworven had. Zijn loopbaan toont aan hoe de Nantese zakenwereld, en vooral de slavenhandel, aan een onderlegd man de kans boden om zich op de sociale ladder omhoog te werken. De weg die hij aflegde van lichtmatroos tot heer van een domein liep over de driehoeksroute.

(102) F.H. 361 ; 366 - Correspondentie J.B. van Damme - J. van Alstein (20 feb., 5 aug. 1795 ; 13 juni 1796); Mémoire a Consulter (Gennes, 8 jan. 1806).

(103) F.H. 64, $\mathrm{n}^{\circ} 219$ - Copij verkoopakte (not. J.B. Maertens - Drongen 24 nov. 1797). 